\title{
LIKOVNE UMJETNOSTI I OBITELJ KOSAČA
}

Tatjana MIĆEVIĆ-ĐURIĆ

Filozofskifakultet

Matice hrvatske b.b.

$\mathrm{BiH}$ - 88000 Mostar

E-pošta: tanjamicevicdjuric@gmail.com

Valerija SOLDO-REŠETAR

Filozofskifakultet

Matice hrvatske b.b.

$\mathrm{BiH}-88000$ Mostar

E-pošta: valerija.soldol@gmail.com
UDK: 72/76:929.5 KOSAČE

Pregledni rad

Primljeno: 1. prosinca 2016

Prihvaćeno: 5. lipnja 2017.

\section{Sažetak}

U radu se analizira odnos obitelji Kosača prema likovnim umjetnostima na temelju sačuvanih graditeljskih ostvarenja čiji su naručitelji Kosače. Ukazuje se na važnost pozicije humske zemlje kao granične sredine u kojoj se dodiruju i isprepleću različiti umjetnički utjecaji te utjecaj naručiteljeva ukusa na umjetnička ostvarenja.

Ključne riječi: Kosače; umjetnost; graditeljstvo; zlatarstvo. 


\section{Uvod}

U srednjem vijeku feudalne su obitelji, uz Crkvu, najistaknutiji naručitelji i donatori umjetnina. Obitelj Kosača, kao jedna od najmoćnijih feudalnih obitelji na izmaku srednjeg vijeka u humskoj zemlji, nije izuzeta iz ovih praksi, unatoč činjenici da se od njihove bogate ostavštine ništa nije sačuvalo. U radu se analizom izvora i pregledom literature, pokušava rasvijetliti odnos obitelji Kosača prema likovnim umjetnostima, njihova naručiteljska djelatnost te veze s umjetničkim centrima na istočnoj obali Jadrana i šire, ne ulazeći u pitanje religijske pripadnosti pojedinih članova obitelji.

\section{Graditeljstvo}

Iako nemamo gotovo nikakvih pouzdanih podataka o umjetničkoj aktivnosti pod Kosačama, njihovim narudžbama čije realizacije $s$ danas mogu vidjeti i ocijeniti, ipak, kada je riječ o graditeljstvu, postoje informacije dobivene na temelju arheoloških i arhivskih istraživanja. Prema dosadašnjim rezultatima tih istraživanja, utvrđena je veza između članova obitelji Kosača i jedne gradske palače te nekoliko sakralnih objekata.

\subsection{Palača Sandalja Hranića u Dubrovniku - javna arhitek- tura Kosača}

Od spomenutih građevina, iako se u ovom slučaju mora imati velika rezerva, najbolje nam je poznata palača Sandalja Hranića u Dubrovniku koja se kasnije nalazi u posjedu Stjepana Vukčića Kosače koji je naslijedio položaj vladara zemlje Kosača. ${ }^{1}$

Za postojanje te palače zna se već dugo. ${ }^{2}$ Međutim, tek prije nekoliko godina, zahvaljujući temeljitim istraživanjima arhivske građe,

1 Potrebnu rezervu objasnit ćemo u nastavku teksta, a odnosi se na činjenicu da je palača, otprije postojeća, pa adaptirana prema željama Sandalja Hranića, odražavala umjetničku klimu Dubrovnika te da nam ostaje nepoznat odnos prema umjetničkom ukusu Kosača i prostora kojima su oni vladali.

2 Prve studije posvećene toj palači objavljene su još 1923. godine. Vidi: VLADIMIR ĆORović, "Palača Sandalja Hranića u Dubrovniku" u: Narodna starina, 2/6/3, Zagreb, 1923., str. 263-264. Vladimir Ćorović, "Sandalj Hranić u Dubrovniku 1426", u: Bratstvo, XVII., Novi Sad, 1923., str. 104, 107. Nakon toga su uslijedila spominjanja te palače u: Risto Jeremić - JorJo TADIĆ, "Prilozi za istoriju zdravstvene kulture starog Dubrovnika, I.", u: Prilo- 
koja su napravili Nada Grujić i Danko Zelić, ta nam se palača ukazala u svojem obliku i s točno utvrđenim fazama adaptacija koje su se događale tijekom gotovo tri desetljeća. ${ }^{3}$

Dubrovačka Republika godine 1405. poklonila je palaču Sandalju Hraniću kao zahvalu za njegovo zalaganje za Republiku kod bosanskih vladara i zaštitu interesa Dubrovnika. ${ }^{4}$ To je bila uobičajena praksa, ${ }^{5}$ ali kasnije darivanje susjedne palače 1419 . godine nakon

zi za istoriju zdravstvene kulture Jugoslavije i Balkanskog poluostrva, sv. 33, Beograd, 1938., str. 18; JoRJo TADIĆ, Promet putnika u starom Dubrovniku, Dubrovnik, 1939., str. 18. Potom su s povijesno-umjetničkog aspekta o palači Sandalja Hranića u Dubrovniku pisali: Cvito Fisković, Naši graditelji $i$ kipari XV. i XVI. stoljeća u Dubrovniku, Zagreb, 1947., str. 58, 103; LuKšA BERITIĆ, "Ubikacija nestalih građevinskih spomenika u Dubrovniku", u: Prilozi povijesti umjetnosti u Dalmaciji, 10, Split, 1956., str. 81-83; Milan PreLOG, "Dalmatinski opus Bonina da Milano", u: Prilozi povijesti umjetnosti u Dalmaciji, 13, Split, 1961., str. 3-8; Cvito Fisković, "Dalmatinski majstori u srednjovjekovnoj Bosni", u: Srednjovjekovna Bosna i evropska kultura, Zenica, 1962., str. 162-263; VoJislav J. Đurić, Dubrovačka slikarska škola [Posebna izdanja SAN, knj. 363; Odeljenje društvenih nauka, knj. 45], Beograd, 1963. str. 253-254; Cvito Fisković, "Neobjavljeni radovi Bonina Milanca u Splitu", u: Zbornik za likovne umetnosti Matice srpske, 3, Novi Sad, 1967., str. 173-174; NADA GRUjIć, "Balatorij u dubrovačkoj stambenoj arhitekturi XV. stoljeća", u: Prilozi povijesti umjetnosti u Dalmaciji, 37, Split, 1997.-1998., str. 140-145 i 151-153. Posljednju i do sada najtemeljitiju analizu Sandaljeve palače nalazimo u Nada Grujić - Danko Zelić, "Palača vojvode Sandalja Hranića u Dubrovniku", u: Anali, 48, Dubrovnik, 2009., str. 47-132.

3 N. Grujić - D. Zelić, nav. dj., str. 47-132.

4 Ljubomir Stojanović, Stare srpske povelje i pisma. Knjiga I, Dubrovnik $i$ susedi njegovi, Prvi deo [Zbornik za istoriju, jezik i kulturu srpskog naroda, Prvo odeljenje, knjiga XIX.], Beograd - Sr. Karlovci, 1929., str. 253-254; V. J. Đurić, nav. dj., str. 254; N. GRUjIĆ - D. Zelić, nav. dj., str. 52-53.

5 Dubrovačka Republika je imala običaj gospodarima prijateljskih zemalja za neke ustupke građanskih prava, darovati nekretnine. Tako su braća Sankovići (vojvoda Radič i župan Beljak, 1390.), bosanski kralj Tvrtko II., vojvoda (kasnije herceg) Hrvoje Vukčić (1399.) i vojvoda Radoslav Pavlović (1427.) dobili kuće u Dubrovniku. Vidi: Jovanka Mijušković, "Dodeljivanje dubrovačkog građanstva u srednjem veku", u: Glas SANU, CCXLVI. [Odeljenje društvenih nauka, knjiga 9], Beograd, 1961., str. 89-130; V. J. Đurić, nav. dj., str. 254; N. Grujić - D. Zelić, nav. dj., str. 50-53.

Tu praksu su imali i druge srednjovjekovne komune, tako da je Sandalj Hranić imao poklonjene kuće i palače u Zadru, Kotoru i Veneciji. Vidi: Ivo STJEPČević - Risto Kovijanić, "Hranići - Kosače u kotorskim spomenicima", u: Istorijski časopis, V., Beograd, 1953., str. 313, 318; N. GRujIĆ - D. Zelić, nav. dj., str. 53. 
darivanja Konavala Republici, ${ }^{6}$ položaj palače u gradu, kao i višestruke adaptacije i izrazito nastojanje da se tom objektu da što reprezentativniji izgled, svjedoče o iznimnom ugledu Sandalja Hranića u Dubrovniku.

Sam položaj palače svjedoči o važnosti koja je u Dubrovniku davana tome objektu. Smještena u neposrednoj blizini Kneževa dvora i Katedrale te na ulazu u grad od Vrata od Ponte, okrenuta svojim stražnjim dijelom prema luci tako da je činila jednu od glavnih vizura pri ulasku u grad, svakako je predstavljala veoma važan element vizualnoga identiteta Dubrovnika u 15. i 16. stoljeću. Naime, palača je bila smještena dvije kuće južno od Kneževa dvora i Vrata od Ponte, otprilike nasuprot apsidi srednjovjekovne dubrovačke Katedrale, srušene u potresu 1667. godine, kada je srušena i Sandaljeva palača i činila je sastavni dio gradskoga zida prema istoku, odnosno, gradskoj luci. ${ }^{7}$

Takav reprezentativni položaj, gotovo izuzetan kada je u pitanju Dubrovnik, u kojem se nastojalo izbjeći mogućnost svakog individualnog isticanja, slijedile su i adaptacije i uređenje palače, čime je dodavana i stalno potvrđivana reprezentativnost toj građevini. Grujić i Zelić su jasno utvrdili tijek građevinskih pothvata. Do 1419. godine, odnosno, do potrebe povezivanja i spajanja dvije kuće u jednu veću, nakon što je Republika darovala i drugu kuću Sandalju Hraniću, nema bitnijih spominjanja građevinskih zahvata na kući darovanoj 1405. godine. Međutim, od 1419. godine, kada je Sandalju darovana i druga kuća, informacije se množe. Iz tih informacija sa sigurnošću se zaključuje kako je Sandaljeva palača, popularno zvana "Hercegovina", trebala u funkcionalnom, dispozicijskom i oblikovnom pogledu ostvariti maksimalnu reprezentativnost, odgovarajuću svojem položaju i značenju unutar gradskog tkiva srednjovjekovnoga Dubrovnika. Već iz 1420. godine potječu dokumenti u kojima se spominje unutarnja reorganizacija prostora dviju spojenih kuća i izgradnja unutarnjeg stubišta koje će iz predvorja voditi na kat. ${ }^{8}$ Slijede potom odluke iz 1421. godine o promjeni broja, položaja i izgleda prozora na palači, a samo nekoliko dana kasnije donesena nova odluka o rušenju pročelja i izgradnji novoga. ${ }^{9}$ Nakon toga, iz gotovo svake naredne

6 Lj. Stojanović, nav. dj., str. 253-254; V. J. Đurić, nav. dj., str. 254; N. Grujić -

D. Zelić, nav. dj., str. 54-55.

7 N. Grujić - D. Zelić, nav. dj., str. 56-62.

8 Isto, str. 71.

9 Isto, str. 63-64. 
godine toga desetljeća postoje podatci o sitnijim intervencijama na popravkama i zamjenama prozora, izradi rešetaka ili pozlaćivanju. $U$ dokumentima je relativno mnogo podataka o gradnji balatorija, koji gradnju toga dijela palače smještaju u $1421 .-1422 .{ }^{10} \mathrm{Iz} 1422$. godine potječe ugovor sklopljen između gradskih vlasti i Bonina iz Milana ${ }^{11}$ koji se angažira na izgradnji balatorija i izradi kamenog, pozlaćenog cimerija koji je trebao biti smješten na pročelju prema luci. ${ }^{12}$ Godine 1423. naručen je zidni umivaonik za glavnu dvoranu Sandaljeve palače. ${ }^{13} \mathrm{Iz} 1425$. godine potječu odluke o ostakljivanju kvadrifore na glavnom pročelju i postavljanju rešetke na njoj te pozlaćivanju prozora, grba i drugih dijelova pročelja, a 1426. godine, očekujući vojvodin dolazak u grad, odlučeno je izraditi još jedan pozlaćeni Sandaljev grb. ${ }^{14}$ Tom prilikom, također, odlučeno je da se zlatom i azurom oslikaju stropovi dviju prostorija na drugom katu i za taj posao pozvan je dubrovački slikar Ivan Ugrinović. ${ }^{15}$

Inače, često je spominjanje pojedinih sitnijih ili većih zahvata na uređenju unutrašnjosti "Hercegovine" koji nam svjedoče kako je palača bila u potpunosti uređena i opremljena prema ukusu toga vremena u Dubrovniku, možda, čak nešto raskošnije i luksuznije nego što je bilo uobičajeno za dubrovačke gradske kuće toga vremena. Tome u prilog govori i podizanje trijema prema Komunalnome trgu, o čemu prve tragove u dokumentima nalazimo, također, 1426. godine, u vrijeme kada se Grad pripremao za dolazak Sandalja Hranića. ${ }^{16}$

10 Isto, str. 66-69.

11 Bonino da Milano, tal. kipar (? - Šibenik, V. 1429.), rodom iz Lombardije. Veći dio života proveo je u Dalmaciji. Prvi put se spominje 1412. u Korčuli, gdje je izradio glavni portal s likom gradskog zaštitnika među lavovima na konzolama i manja vrata s reljefnim likom sv. Jakova na pročelju katedrale, te reljef sv. Petra za istoimenu crkvu. Stupivši u službu Dubrovačke Republike surađuje 1417. na gradnji crkve sv. Vlaha kojoj 1424. dovršava kor, te obavlja niz zadataka od kojih je većina uništena u velikom potresu 1667. U Splitu izvodi više radova, a najznatnije mu je ostvarenje kapela sv. Dujma u splitskoj katedrali. U Šibeniku je imenovan za prvog majstora stolne crkve za koju je isklesao većinu skulptorskih elemenata glavnog portala.

"Bonino da Milano" u: Enciklopedija likovnih umjetnosti, 1, Zagreb, 1959., str. 433-434.

12 N. Grujić - D. Zelić, nav. dj., str. 69.

13 Isto, str. 75.

14 Isto, str. 64.

15 V. J. Đurić, nav. dj., str. 254; N. Grujić - D. Zelić, nav. dj., str. 76.

16 N. Grujić - D. Zelić, nav. dj., str. 77. 


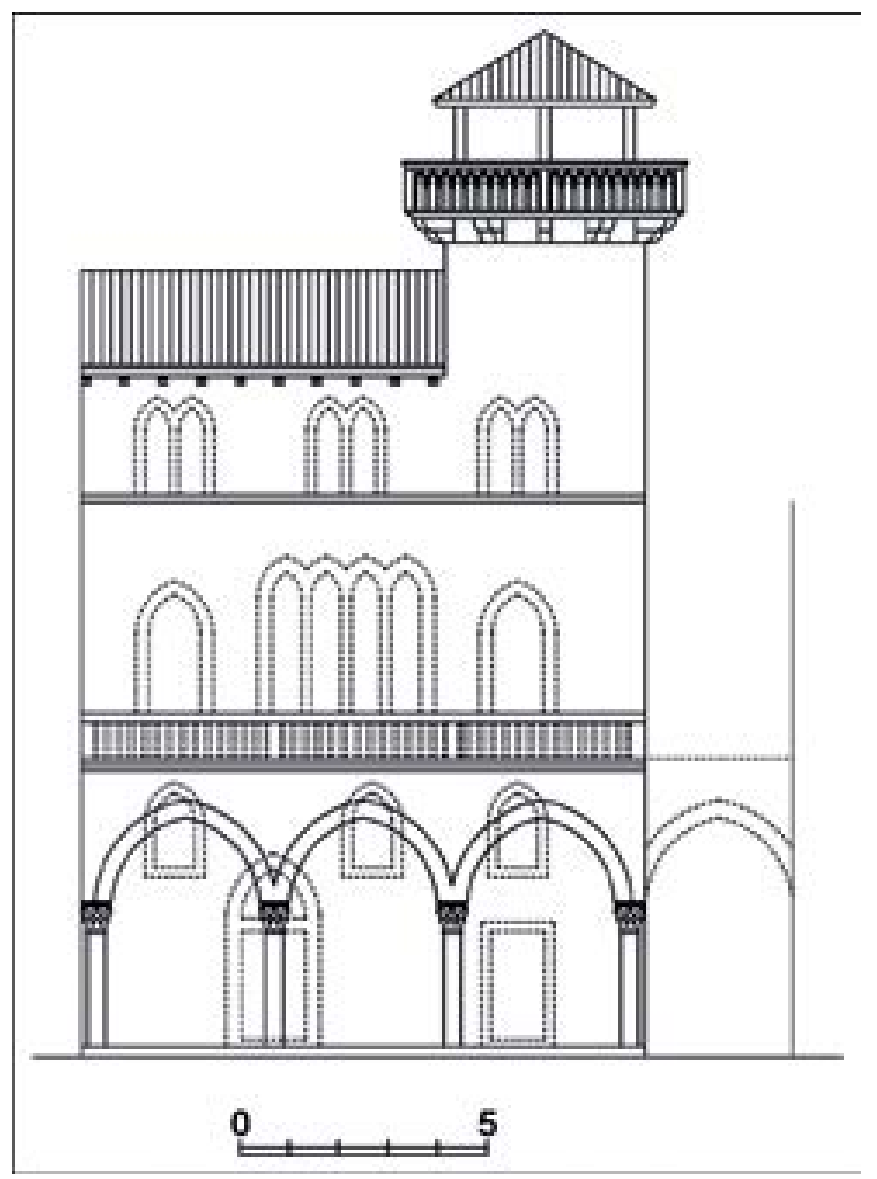

S1. 1. Prikaz mogućeg izgleda pročelja palače Sandalja Hranića u Dubrovniku Preuzeto iz: NADA Grujić - DANKo Zelić, "Palača vojvode Sandalja Hranića u Dubrovniku", u: Anali, 48, Dubrovnik, 2009., str. 78.

Iz svih spominjanja palače Sandalja Hranića, opisa planiranih radova, kao i drugih dokumenata u kojima se vojvodina palača, odnosno, neki njezini dijelovi navode kao uzor drugim gradnjama te na temelju nekoliko veduta Dubrovnika na kojima se ona vidi, relativno dobro se može rekonstruirati njezin izgled, preciznije, izgled zapadnoga pročelja (slika 1). Palača je imala četiri etaže - prizemlje i prvi kat koje je obuhvaćao trijem svojom visinom, drugi kat koji je prema običajima toga vremena bio piano nobile o čemu svjedoči i kvadrifora spomenuta u dokumentima te treći kat u razini kojega su na zapadnoj 
strani bile tri bifore. Izgled trijema nije siguran. Imao je tri ili četiri prelomljena luka, oblik koji je bio stalno tražen i primijenjen na svim prozorima. Balatorij kvadratnoga tlocrta s balustradom ili perforiranom ogradom oslonjenom na konzole, nalazio se iznad južnog dijela palače. S mnogo manje sigurnosti se može govoriti o prostornoj dispoziciji i unutarnjem uređenju Sandaljeve palače. ${ }^{17}$ Međutim, jasno je kako je palača bila organizirana, uređena i opremljena u najboljoj tradiciji onovremene reprezentativne rezidencijalne arhitekture $\mathrm{u}$ okviru onih tokova koji su u našim krajevima bili prihvaćeni. Postoje brojni podatci o uređenju pojedinih elemenata, a zapisi o pozlatama, nabavkama zlata i azura, angažiranju vodećih majstora Republike za radove na njoj, svjedoče njezinu reprezentativnost. U skladu s time je i potvrda da je jedini danas preostali materijalni ostatak Sandaljeve palače, nastao u vrijeme njezina prvog uređenja, bila i kruna bunara koja se danas nalazi u tvrđavi Revelin u arheološkoj postavci Dubrovačkih muzeja. ${ }^{18} \mathrm{Na}$ sve četiri stranice glavni motiv je veliki grb Kosača, sastavljen od lava, zastave s križem, štita s prugama i akantusove vitice, nešto predimenzioniran u odnosu na veličinu stranice. Grb je smješten u ovalno polje uokvireno akantusom koji se penje do gornjega dijela brida krune, gdje je s akantusom sa susjedne stranice spojen jednostavnim cvijetom jednostrukoga reda latica. Ta kruna pokazuje osobine gotičkoga stila, ali činjenica da su sve četiri stranice bile jednako oblikovane i da im je pridana jednaka važnost, govori o tome da je bila postavljena u središte predvorja i da je činila važan element unutarnjega oblikovanja prizemlja palače.

Prema svemu rečenome zaključuje se da je palača Sandalja Hranića koja se nalazila na istaknutome i veoma važnome mjestu u gradu, nel più bello logo della città, ${ }^{19}$ predstavljala reprezentativan primjer dubrovačke gotičke rezidencijalne arhitekture na početku 15. stoljeća. Ona je odražavala ukus dubrovačke sredine u kojem je gotika

17 Pretpostavke o tlocrtima po etažama daju Grujić i Zelić. Vidi: Isto, str. 70-74.

18 Prvi je krunu bunara Kosačama, odnosno, palači "Hercegovina" pripisao Pavo Anđelić, ali nije bio siguran kojem od vlasnika palače, prvome - Sandalju ili njegovu nasljedniku - hercegu Stjepanu Kosači ona pripada. Bio je skloniji mišljenju da se treba vezati uz hercega Stjepana. Vidi: Pavao ANĐELIĆ, "Grbovi hercega Stjepana Vukčića Kosače na kruni jedne kućne cisterne u Dubrovniku", u: Tribunia, 1, Trebinje, 1975., str. 83-90. Konačno i definitivno tu krunu na temelju arhivskih dokumenata Sandalju Hraniću pripisuju Grujić i Zelić. Vidi: N. Grujić - D. Zelić, nav. dj., str. 50, 74-75.

19 N. Grujić - D. Zelić, nav. dj., str. 57, bilj. 36. 
bila dominantan umjetnički izričaj, tako da se sve elemente, kako prostorne dispozicije i elevacije (balatorij, trijem, oblik lukova), pa prema tome i elemente klesane dekoracije, izgubljene u potresu, kao i ostale elemente objekta i njegove opreme te uređenje palače određuje gotički stil.

To nam ipak ne govori gotovo ništa o sklonostima vojvode Sandalja i njegove obitelji, o umjetničkim potrebama i navikama, ukusima gospodara Zahumlja. Palača "Hercegovina" je narudžba i oličenje ukusa dubrovačke sredine. Moguće je da je ponešto neuobičajena reprezentativnost posljedica ukusa osobe kojoj je poklonjena, ali je prije moguće da je to bio način dodvoravanja i povlađivanja važnome savezniku i partneru koji je bio nesumnjivi prijatelj Republike. Prema riječima dubrovačkih poslanika Sandalju, nije se pamtilo da je od svoga osnutka Grad s nekim velikašem bio u većem prijateljstvu nego što je to bio s njim samim, ${ }^{20} \mathrm{i}$ kao da su to htjeli dokazati i izgledom palače.

Međutim, iz česte prepiske s gradskim vlastima, jasno je i kako je Sandalj Hranić ne samo primao ono što mu je Dubrovnik davao, nego i da je postavljao izvjesne zahtjeve koji su bili jasno određeni i, veoma često, zahtijevali ponekad i više od onoga što su Dubrovčani sami bili planirali. Iz njegovih se zahtjeva može shvatiti kako je on bio dobro upoznat s onovremenim umjetničkim tokovima i ukusima, što je u skladu s činjenicom da je bosanska i humska vlastela održavala česte i veoma tijesne odnose ne samo s Dubrovnikom, nego i s drugim primorskim gradovima, odakle su dobivali spoznaje o aktualnim kretanjima u različitim umjetničkim granama. ${ }^{21}$

Zato bi bilo opravdano pretpostaviti kako su i u gradovima u zemlji Kosača u Sandaljevo vrijeme i u vrijeme njegova nasljednika Stjepana Vukčića Kosače mogle biti građene palače sličnih oblika kao one koje su u primorskim gradovima gospodari Zahumlja posjedovali, odnosno, da su palače zahumske vlastele građene u njihovoj zemlji preuzimale neka oblikovna svojstva rezidencijalne arhitekture uobičajene u gradovima na istočnoj obali Jadrana. Međutim, veoma je malo, ili uopće nema materijalnih ostataka koji bi to potvrdili. Izniman je primjer stari grad Blagaj kod Mostara u kojem su arheološka istraživanja utvrdila postojanje palače koja je predstavljala najzna-

20 Isto, str. 51, bilj. 8.

21 Sandalj, a osobito njegova žena Jelena, često su upućivali narudžbe u zlatarske radionice Dubrovnika i Kotora. Vidi: V. J. ĐuRIĆ, nav. dj., str. 252-256. 
čajniji objekt unutar grada, čiji je tlocrt imao oblik izduženoga nepravilnog četverokuta i koja je imala trijem sa stupovima ukrašenim plastičnim dekoracijama. ${ }^{22}$ Palača je datirana na kraj 14 . i početak 15. stoljeća, u vrijeme vojvode Sandalja Hranića. ${ }^{23}$ Takvi elementi daju opravdanje pretpostavci o postojanju palača nalik primorskima i u zemlji Kosača, ali u drugim gradovima, Samoboru kod Goražda ili Sokolu na Šćepan Polju, važnim gradovima Kosača koji su relativno dobro arheološki istraženi, nisu pronađeni slični tragovi njihova postojanja. Nameće se pretpostavka kako je fortifikacijski karakter gradova u zemlji Kosača, njihov položaj na vrhovima uzvisina, zatvorenost unutar zidina, ojačanih kulama, učinio neprikladnim gradnju gotičkih palača s trijemovima i velikim otvorima, premda je vlastela bila upoznata s oblicima i opremom reprezentativnih gradskih palača iz primorskih gradova, i bila ih sklona prihvatiti.

\subsection{Sakralna arhitektura Kosača}

Kada je u pitanju sakralna arhitektura koja se veže uz donatorstvo Kosača, poznato nam je pet crkava koje su izgradili Sandalj Hranić, njegova žena Jela i Sandaljev nasljednik Stjepan Vukčić Kosača. Te građevine se mogu relativno dobro rekonstruirati, ali nedostaju informacije o detaljima poput ukrasa na pročeljima i dijelova unutarnjeg opremanja te zidnih slika.

Jedina za sada poznata ostavština Sandalja Hranića je crkva sv. Stjepana na Šćepan Polju, ${ }^{24}$ inače najveća crkva koja je u prvoj polovici 15. stoljeća izgrađena na području kojim su vladale Kosače. Crkva se nalazila ispod grada, u sredini Šćepan Polja i bila je monumentalna, ukupne dužine s narteksom preko $25 \mathrm{~m}$ i širine narteksa i naosa s pijevnicama od otprilike $10 \mathrm{~m} \cdot{ }^{25} \mathrm{Na}$ temelju preostalih dijelova crkve - ostataka zidova mjestimično do $4 \mathrm{~m}$ visine te ulomaka pronađenih

22 Na lokalitetu je pronađen kapitel jednog pilastra.

23 Potpun popis literature koja se bavi ovim srednjovjekovnim gradom nalazi se na: http://old.kons.gov.ba/main.php?id_struct=6\&lang=1\&action=view\& $\mathrm{id}=1863$ (22. 11. 2016.).

24 Grad Sokol, najvažniji grad Kosača u prvoj polovici 15. stoljeća, najvjerojatnije se nalazio na Śćepan Polju. Na žalost, malo je sigurnih povijesnih podataka o tom gradu. Njihov pregled daje se u: MARko Popović, "Soko grad nad Šćepan Poljem", u: Šćepan polje i njegove svetinje kroz vjekove - Zbornik radova sa naučnog skupa, Berane, 2010., str. 18-19.

25 Isto, str. 21, 45. 
tijekom arheoloških istraživanja lokaliteta ${ }^{26}$ dolazi se do podataka o arhitekturi crkve i fazama njezine izgradnje.

Crkva je izgrađena bez narteksa, a tlocrt najstarije faze izgradnje crkve bio je u obliku slobodnoga grčkog križa s nepravilnostima u ostvarivanju pravoga kuta, tako da zbog toga dolazi do laganoga odstupanja od orijentacije istok - zapad, koja je planirana (slika 2). Zapadni travej, do izgradnje novoga velikoga narteksa, vjerojatno je služio kao narteks. ${ }^{27}$ Sjeverni i južni travej mogu se shvatiti pijevni-

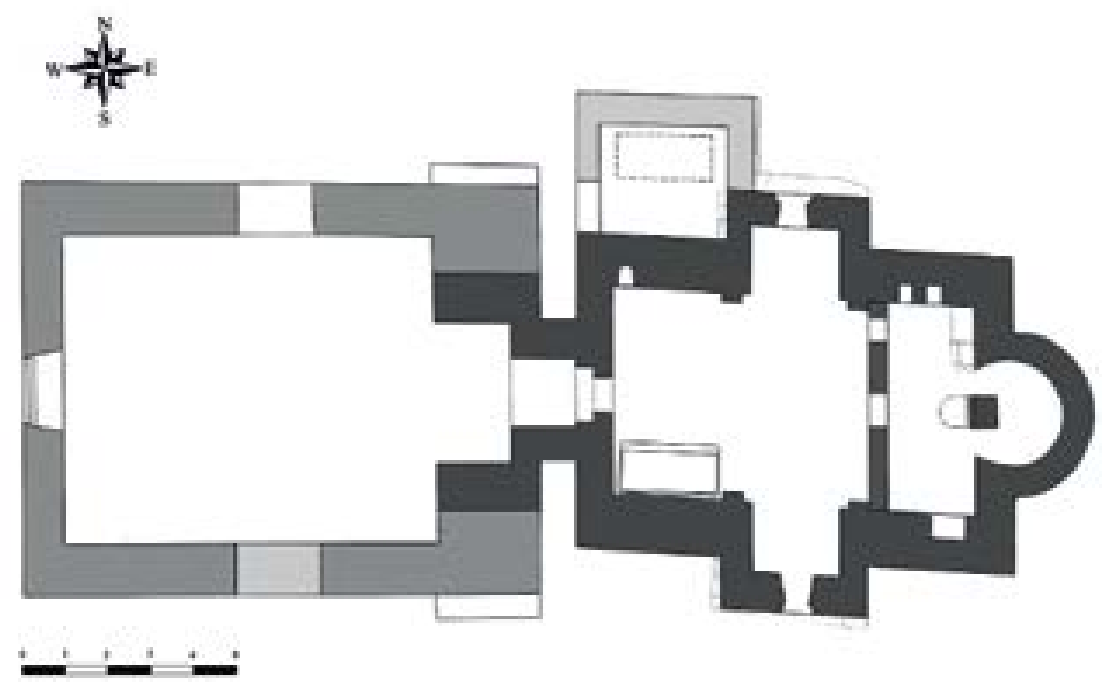

Sl. 2. Tlocrt crkve sv. Stjepana na Šćepan Polju Preuzeto iz: Marko Popović, "Soko grad nad Šćepan Poljem", u: Šćepan polje i njegove svetinje kroz vjekove - Zbornik radova sa naučnog skupa, Berane, 2010., str. 45.

26 Prva arheološka istraživanja izvršena su 1971.-1973. godine pod vodstvom V. J. Đurića. Istraživanja su poduzeta u sklopu priprema za konzervaciju ostataka crkve ugrožene planiranom izgradnjom hidrocentrale na Drini koja bi izazvala potapanje Šćepan Polja. Ti planovi nisu realizirani, crkva je konzervirana, ali rezultati istraživanja do sada nisu još objavljeni. Vidi: M. Popović, nav. dj., str. 19.

27 U zapadnome traveju nalazi se jedna grobnica označena velikim stećkom. Vjeruje se da je tu sahranjen vojvoda Sandalj Hranić, donator crkve, što bi bilo potpuno u skladu s običajima srednjovjekovnih vladara na prostorima koji su bili izloženi utjecaju bizantske tradicije. Jugozapadni kut crkve bio je rezerviran za grobove vladara ili za donatore crkve. U slučaju crkve sv. 
cama karakterističnima za srednjovjekovne raške crkve, prostorno bliske i Šćepan Polju. Istočni travej je služio kao prezbiterij i bio je odvojen od naosa zidanom oltarskom pregradom u kojem su bila otvorena dva prolaza - centralni i bočni u sjevernome dijelu pregrade (ikonostasa?). Taj krak križa završavao je potkovičastom apsidom. Brojni ulomci svjedoče postojanje svoda, najvjerojatnije gotičkoga tipa s presjekom u obliku prelomljenog luka koji je bio ojačan dvama pojasnicama koje su se oslanjale na pilastre prizidane uza sjeverni i južni zid u istočnome i zapadnome traveju crkve. Prijelaz u svod bio je označen profiliranim vijencem. Pijevnice su također bile nadsvođene nižim polukružnim svodovima, postavljenima okomito na os glavnoga. Crkva nije imala kupolu.

Relativno je dosta ulomaka arhitektonske plastike koja nam predočava nekadašnji izgled crkve sv. Stjepana. Najinteresantniji je izgled vijenca koji je išao ispod dvovodnoga krova kojim je crkva bila pokrivena. Suprotno uobičajenom frizu visećih slijepih arkadica, na konzolice je bio oslonjen jednostavan vijenac u obliku tordiranoga užeta. Prozori, osobito oni u istočnome traveju, bili su nešto dekorativnije oblikovani. Najreprezentativniji prozor, trifora bez koloneta, nalazio se na apsidi, a njegov izgled može se predočiti na temelju ulomaka jednoga natprozornika prozora koji se nalazio na zidu istočnoga traveja, na kojem se vidi prelomljeni luk, uokviren jednostavno profiliranim pravokutnim okvirom unutar kojega se u gornjem dijelu, slijedeći oblik luka i popunjavajući preostali prostor širi jednostavni vegetabilni ornament izveden u reljefu, dok je linija otvora prozora ukrašena ornamentom dijamantnih vršaka. ${ }^{28} \mathrm{Na}$ crkvi se nalazio i skromno ukrašeni visoki, uski portal čije proporcije ukazuju na gotičke utjecaje. Ispred njega se nalazila neka jača konstrukcija, potpuno neuobičajena, o čijem značenju i funkciji se danas ništa ne može sa sigurnošću reći. ${ }^{29}$

Stjepana na Šćepan Polju, oba kriterija su ispunjena. Uz položaj groba koji svjedoči o želji da se poštuje takva tradicija, postavljanje monumentalnoga stećka govori o postojanju svijesti o pripadnosti sredini u kojoj su stećci bili dominantan oblik nadgrobnoga spomenika, različit od nadgrobnika u susjednim srpskim zemljama koji su se nalazili na istim mjestima u crkvama, ali su bili drugačijih oblika. Vidi: DANica Popović, Srpski vladarski grob, Beograd, 1992.

28 Isto, str. 23.

29 Ta je struktura bila visoka, tako da je najprihvatljivija pretpostavka da je riječ o zvoniku. Na žalost, bez analognih komparativnih primjera, teško je bilo što sa sigurnošću govoriti. Vidi: M. Popović, nav. dj., str. 23. 
Naknadno su uz crkvu dozidana dva aneksa - veliki narteks na zapadu i jedna mala kapela uz sjeverozapadni zid crkve. U toj kapelici malih dimenzija, vjerojatno bez svoda, ${ }^{30}$ nalazio se veliki stećak, danas devastiran, ispod kojega je bio izvršen ukop ${ }^{31}$ što govori o funeralnoj funkciji aneksa, no bez dokumenata ili nalaza ne može se pretpostaviti identitet ukopane osobe.

Drugi dodatak prvotnoj crkvi je veliki narteks za kojeg se može reći da je bio gotovo dominantan element u konačnome izgledu crkve sv. Stjepana. Ta jednobrodna građevina koja ponavlja širinu naosa crkve, dužine gotovo jednake čitavoj crkvi, povezana je s neuobičajenom konstrukcijom - zvonikom (?) na istočnoj strani. Bila je bez svoda, s ravnom stropnom konstrukcijom od greda oslonjenih na snažne konzole. U unutrašnjosti crkve, i naosa i narteksa, ali i grobne kapele, izgleda da su svi zidovi bili oslikani freskama. Iako od toga slikarstva gotovo ništa nije ostalo, osim maloga dijela glave s kovrčavom kosom i donjih dijelova slikanoga sokla, jasno je da je riječ o slikarstvu koje je slijedilo bizantsku tradiciju, o čemu ponajprije svjedoče srpske ćirilične signature. Međutim, način slikanja koji je minimalno vidljiv na fragmentu s kovrčama kose, ali i arhivski izvori koji govore o tome da je Ivan Ugrinović, značajan slikar dubrovačke kasne gotike, na izričiti zahtjev vojvode Sandalja, nakon što je vidio kako je zlatom i azurom ukrasio strop njegove palače u Dubrovniku, bio poslan vojvodi 1429. godine i da se Ugrinović na tom zadatku zadržao gotovo godinu dana, ${ }^{32}$ ukazuju na mogućnost da je Ugrinović upravo bio tražen radi oslikavanja crkve sv. Stjepana.

Taj arhivski podatak, uz poznatu godinu smrti vojvode Sandalja Hranića - 1435., vrijeme kada je crkva bila potpuno završena, daju elemente za njezinu dataciju. Prema tome, prva crkva je mogla biti građena početkom trećeg desetljeća 15. stoljeća. Vjerojatno su aneksi dograđeni samo nekoliko godina kasnije, o čemu svjedoči isti način gradnje narteksa i crkve i veoma slična klesana dekoracija. Svi prostori su bili istodobno oslikani krajem toga desetljeća. Prema svemu tome, crkva sv. Stjepana bila je dovršena, sa svim svojim fazama, do

30 Isto, str. 28.

31 Ukopi su vršeni u svim dijelovima crkve sv. Stjepana, osim ispod spomenutoga stećka u zapadnome kraku i ovoga u grobnoj kapelici, grobovi su otkriveni i u narteksu i u naosu, kao i na čitavome prostoru oko crkve.

32 JoRjo TADIć, Građa o slikarskoj školi u Dubrovniku XIII - XVI veka, Beograd, 1952., str. 79; V. J. ĐuRIĆ, nav. dj., str. 243. 
jeseni 1429. godine i potpuno spremna da primi zemne ostatke velikoga vojvode.

Već je rečeno kako se ne zna komu je bila namijenjena sjeverna grobna kapela uz crkvu sv. Stjepana na Śćepan Polju. Moguće je da je bila namijenjena ukopu Sandaljeve udovice Jelene, sestre despota Stevana, udane prvo za Đurđa Stracimirovića Balšića, ali se pouzdano zna da ona tu nije ukopana. Vjeruje se kako je ona pokopana u Bogorodičinoj crkvi na Brezavici, koju je ona dala sagraditi, što saznajemo prema natpisu sačuvanome na nadvratniku te crkve u kojem se navodi da je 1440. godine crkvu podigla Jela, kći kneza Lazara, udovica Đorđa Stratimirovića i Sandalja Hranića. ${ }^{33}$

Crkva je jednobrodna, malih dimenzija - dugačka, okvirno, 6,5 metara, a široka 4,5 metra. ${ }^{34}$ Jednim parom pilastara prislonjenih na sjeverni i južni zid podijeljena je na dva traveja jednake veličine. $\mathrm{Na}$ istoku ima jednu polukružnu apsidu i dvije polukružne niše za proskomidiju i đakonikon. Crkva je pokrivena prelomljenim svodom ojačanim jednom pojasnicom oslonjenom na pilastre. Ništa osim nekoliko fragmenata stupova nije sačuvano od klesane dekoracije. Ti stupovi su se nalazili u prigradnjama čiji se temelji nalaze oko crkve - dva trijema prislonjena uz sjeverni i južni zid crkve te narteks u zapadnome dijelu. ${ }^{35}$

Crkva je vjerojatno bila i oslikana, ali o unutarnjem oslikavanju nisu sačuvani nikakvi dokazi, dok su tragovi fresaka na vanjskome zidu unutar slijepih niša na zapadnome pročelju bili vidljivi još u prvoj polovici 20. stoljeća. ${ }^{36}$

Te slijepe niše predstavljale su rijetke elemente dekoracije pročelja. Bile su smještene u gornjoj zoni, postavljene simetrično u odnosu na portal, tako da se najveća nalazila u njegovoj osi, a dvije manje lijevo i desno od nje. Iznad njih je bio jedan visoki, uski, lučno zasvedeni prozor i na vrhu element sličan trolučnome zvoniku "na preslicu".

33 ĐurĐe BošKović, "Izveštaj i kratke beleške sa putovanja", u: Starinar, III. serija, VI., Beograd, 1931., str. 161- 162; LJ. STOJAnOvić, nav. dj., str. 394-397, br. 400; V. J. ĐuRIĆ, nav. dj., str. 255.

34 Đ. BošKović, nav. dj., str. 161.

35 Isto.

36 Isto. 

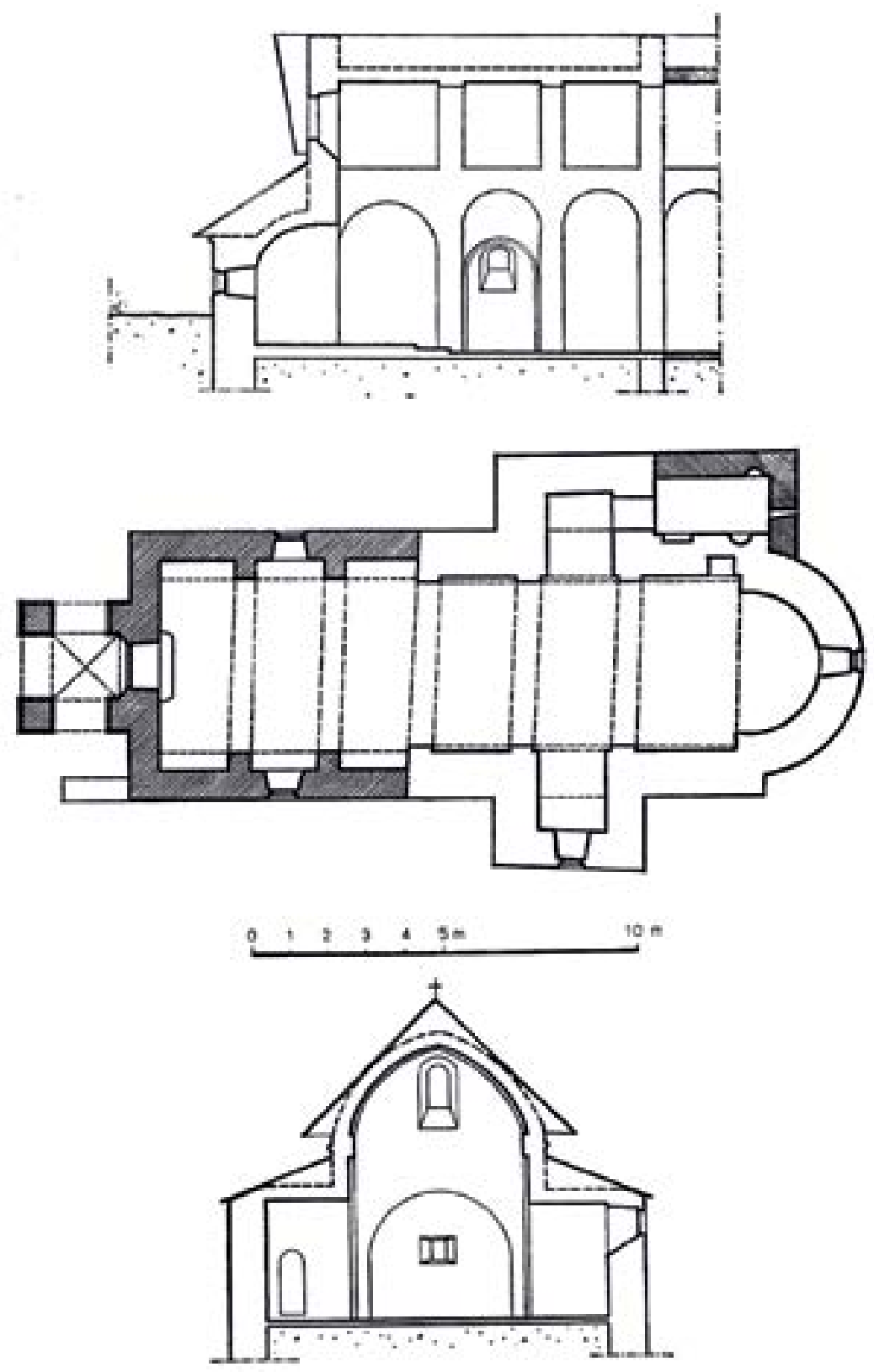

S1. 3. Tlocrt crkve sv. Đorđa u Sopotnici kod Goražda

Preuzeto iz: Dragan Vojvodić, "Ktitorska delatnost Stjepana Vukčića Kosače", u: Šćepan polje i njegove svetinje kroz vjekove - Zbornik radova sa naučnog skupa, Berane, 2010., str. 88. 
Ostale tri crkve Kosača podigao je Stjepan Vukčić Kosača. ${ }^{37}$

Najstarija od njih je već dugo poznata i s njim povezivana crkva sv. Đorđa u Sopotnici kod Goražda (slika 3). Ta je crkva, prema natpisu uklesanome na nadvratniku, izgrađena 1454 . godine. ${ }^{38}$ Upravo zahvaljujući tom natpisu, ta je crkva i najpoznatija ostavština Kosača.

Crkva je nastajala u nekoliko faza. Najstariji dio sličan je prvotnoj crkvi sv. Stjepana u Śćepan Polju, ali ne ponavlja oblik slobodnoga grčkoga križa, nego se grčki križ sužava u sjevernome i južnome kraku, dok se zapadni - narteks i istočni - prezbiterij, produžavaju. Istočni dio završava polukružnom apsidom. Ta je crkva bila nadsvođena prelomljenim, izrazito visokim svodom ojačanim pojasnicama i bila je bez kupole. Naknadno, ali ne dugo nakon gradnje crkve, dozidana je kapela u sjeveroistočnome dijelu, uglavljena između sjeverne pijevnice i oltarske apside iz koje se ulazilo u taj jednostavni pravokutni paraklis. Dok se tom prigradnjom nije bitnije utjecalo na izmjenu crkvenoga prostora, intervencija iz 16. stoljeća ga je u dosta velikoj mjeri promijenila. Tada je zbog želje da se prostor crkve poveća, zapadni dio dograđen i preuređen u veći nadsvođeni narteks.

Nisu sačuvani nikakvi ulomci klesane arhitektonske dekoracije. Jedino je preostao jednostavno profilirani završni vijenac na sjevernom i južnom pročelju te apsidi. Iz toga bi se moglo zaključiti kako crkva nije ni bogatije bila ukrašena na svojim pročeljima. ${ }^{39}$ Unutarnji zidovi su bili raščlanjeni plitkim lezenama povezanima lukovima čiji je raspored odgovarao rasporedu pojasnica. U crkvi se nalazio zidani ikonostas, koji je iz crkve uklonjen u 19. stoljeću. ${ }^{40}$ Ikonostas je imao dva prolaza, središnji - "carski" i sjeverni, što ponavlja rješenje ostvareno petnaestak godina ranije u crkvi sv. Stjepana, koju je podigao

37 Stjepan Vukčić Kosača je 1448. godine sebi dodijelio titulu hercega. Vidi: Sima Ćirković, Stefan Vukčić Kosača i njegovo doba, Beograd, 1964., str. 106.

38 Natpis se prvotno nalazio na nadvratniku portala, a onda je prilikom proširivanja crkve u zapadnome dijelu, stari portal rastavljen, a dio s natpisom ugrađen u dovratnik novoga. Inače, o natpisu je dosta pisano i raspravljano o datumu i spomenu "hercega" Stjepana u godini prije njegova uzimanja te titule. Kompletna literatura je dana u: Đoко Mazalić, "Hercegova crkva kod Goražda i okolne starine", u: Glasnik zemaljskog muzeja, LII., Sarajevo, 1940., str. 37-39; ZdRavko Kajmaković, Zidno slikarstvo u Bosni i Hercegovini, Sarajevo, 1971., str. 56-58.

39 Nisu utvrđeni ulomci okvira prozora ili vrata.

40 Đ. MaZALIĆ, nav. dj., str. 32. 
vojvoda Sandalj. Inače, zidani ikonostasi s dva prolaza mogu se smatrati elementom koji omogućava datiranje crkve u 15. stoljeće, budući da se od 16. stoljeća pojavljuju drveni ikonostasi koji postaju redoviti nakon 16. stoljeća. ${ }^{41}$

Najvažniji dio dekoracije crkve sv. Đorđa u Sopotnici svakako su bile freske. ${ }^{42}$ Njihovi ulomci su se mogli vidjeti još krajem 19. stoljeća, o čemu postoje pisana svjedočenja koja spominju figuru arkanđela Mihajla na zidu južne pijevnice. ${ }^{43} \mathrm{Na}$ žalost, zbog potpunog gubitka bilo kakvih tragova tih zidnih slika, nemoguće je reći nešto o provenijenciji slikara i slikarstva, ikonografskom programu ili dataciji. Prema mišljenju Z. Kajmakovića moglo bi se jedino smatrati vjerojatnijim da je crkva bila oslikana u vrijeme hercega Stjepana, a ne u vrijeme dogradnje narteksa u 16. stoljeću. Tada je oslik mogao biti proširen, uz popravke postojećega, i na zidove novonastaloga dijela crkve, ali nikada nisu poduzeta istraživanja kojima bi se to provjerilo. ${ }^{44}$

Dok uopće nije upitno je li Stjepan Vukčić Kosača podigao crkvu sv. Đorđa u Sopotnici, jer to potvrđuje sačuvani natpis koji ujedno crkvu precizno i datira, dotle je dosada još uvijek nesigurno pripisivanje male Bogorodičine crkve u manastiru Savini tom naručitelju (slika 4). Povezivanje te crkve i hercega Stjepana izvodi se na temelju podataka uzetih iz deftera sandžaka Hercegovine ( $\left.\mathrm{N}^{\circ} 484\right)$ iz 1585. godine. ${ }^{45} \mathrm{U}$ tom defteru crkva se ne spominje imenom, ali prema mišljenju D. Vojvodića, a ranije i V. J. Đurića, ${ }^{46}$ veličina i oblik male crkve u Savini po svemu odgovaraju crkvi o kojoj se govori u tom defteru. ${ }^{47}$ Pretpostavku o vezi hercega Stjepana s podizanjem te

41 Isto.

42 Sasvim je sigurno, o čemu svjedoči velika količina žbuke s tragovima fresaka "sahranjena" u dvorištu crkve, zapadno od nje, da su zidovi bili oslikani. Vidi: Zdravko Kajmaković, "Drina u doba Kosača", u: Naše starine, XIV.XV., Sarajevo, 1981., str. 160-161.

43 (Z)EČEvić, "Zadužbina hercega Stefana kod Goražda", u: Bosanskohercegovački istočnik, Sarajevo, 1890., str. 244-247.

44 Z. Kajmaković, nav. dj., 1981., str. 161.

45 Dragan Vojvodić, "Ktitorska delatnost Stjepana Vukčića Kosače", u: Šćepan polje i njegove svetinje kroz vjekove - Zbornik radova sa naučnog skupa, Berane, 2010., str. 63.

46 Vojislav J. Đurić, "Mileševa i drinski tip crkve", u: Raška baština, 1, Kraljevo, 1975., str. 19; Isti, Savina, Beograd, 1977., str. 15.

47 D. Vojvodić, nav. dj., str. 63. 

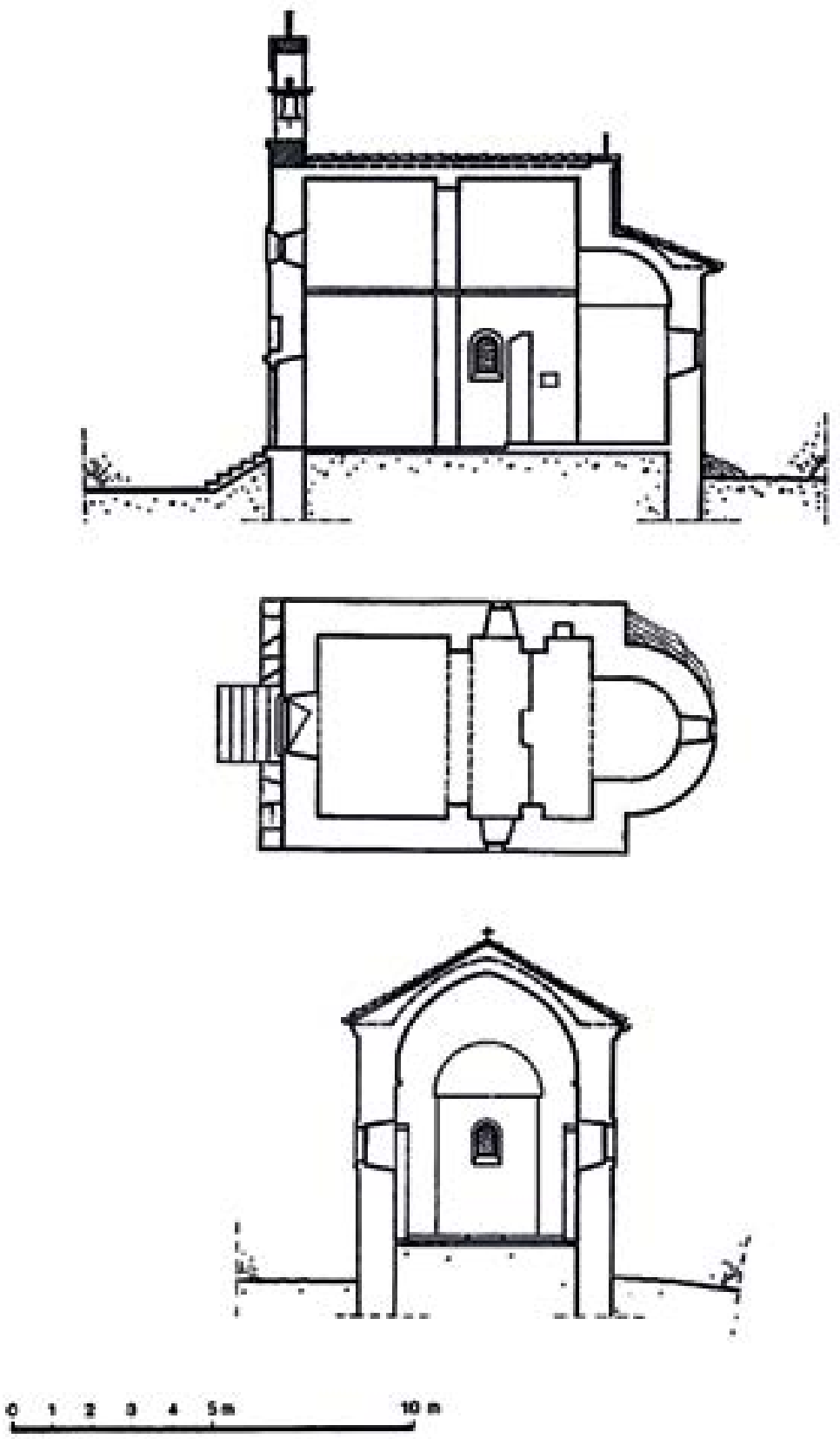

Sl. 4. Tlocrt Bogorodičine crkve manastira Savina Preuzeto iz: Dragan Vojvodić, "Ktitorska delatnost Stjepana Vukčića Kosače", u: Šćepan polje i njegove svetinje kroz vjekove - Zbornik radova sa naučnog skupa, Berane, 2010., str. 89. 
crkve potvrđuje i činjenica da je Herceg Novi u to vrijeme bio u vlasti hercega Stjepana, čak je bio njegovo zimsko prijestolno mjesto. ${ }^{48}$ Premda ne postoje nikakvi natpisi na samoj crkvi, a arhitektonskim tipom jednobrodne crkve s prelomljenim svodom ojačanim dvjema pojasnicama koje dijele crkvu na tri traveja, arhitektura crkve ne podupire, ali niti pobija pretpostavku o vezi s hercegom Stjepanom, Bogorodičina crkva u Savini bi se doista mogla povezati s njim kao donatorom.

Takvom zaključku u prilog govori i karakter fresaka izvedenih u oltarskome prostoru neposredno nakon izgradnje crkve. Ikonografski program toga slikarskog pothvata poštivao je ustaljena ikonografska pravila svojstvena bizantskoj umjetničkoj tradiciji, što je najočitije u tradicionalnom ikonografskom rješenju s Bogorodicom Platiterom u kaloti apside i Povorkom liturgičara u najnižoj zoni. ${ }^{49}$

Za razliku od ikonografije odstupanja toga slikarstva od bizantske umjetničke tradicije su znatno veća na razini formalno-stilskih osobina. Svojim stilom te se freske prije uklapaju u tokove gotičkoga slikarstva, nego što ostaju bizantske. "Svetitelji pripadaju tipu kakav se na zapadnom Mediteranu tada često pojavljuje: lica su, skoro redovno, sa usko prorezanim očima, ponekad dosta ukošenim, i s istaknutim jagodicama, a draperije su čvrsto modelovane sa naborima koji se oštro prelamaju. Osnovni sklad boja - zelena i crvena, naročito cinober, inače redak u fresko-slikarstvu - pripada zreloj gotici. U njega se utkiva žuti oker i siva ili tamnoplava boja. Na naslikanom nameštaju su najvidljivije gotičke crte u ornamentici i oblicima (klupa u Duhovima, ciborium u Blagovestima itd.)." ${ }^{50}$ To slikarstvo u maloj

48 S. Ćirković, Herceg Stefan Vukčić Kosača i njegovo doba, str. 267.

49 Ipak u izvedenome programu uočavaju se i određene posebnosti. Prije svega, ciklusu Velikih blagdana dan je historijski karakter, narušen u vrijeme makedonske dinastije i nastajanja klasičnoga programa oslikavanja bizantskih hramova zbog usklađivanja sadržaja i značenja scena i simbolike ili liturgijske funkcije pojedinih prostora. Najveća se odstupanja uočavaju u srednjoj zoni apsidalnoga zida, gdje su prikazane četiri scene iz ciklusa Muke Kristove. Iako kompozicija Pričešća apostola nije nepoznata bizantskoj umjetničkoj tradiciji njezino prikazivanje u sastavu ciklusa koji posjeduje historijski, narativni, a ne simbolički karakter iskazivanja sadržaja, posve je neuobičajeno. Ta se pojava može objasniti lokalnim posebnostima, kao što je prikazivanje scena Stradanja, Raspeća i događaja neposredno vezanih za Kristovu smrt, koje se u 14. stoljeća pojavilo u nekim kotorskim crkvama zapadnoga obreda.

50 Valjana stilska analiza tih fresaka danas je nemoguća zbog lošega stanja očuvanosti oslika. Osim toga, zbog propisa pravoslavnoga obreda, nije mi bio 
crkvi manastira Savina na temelju stilskih obilježja pripisano je Lovri Dobričeviću te u okviru poznatih i sigurno datiranih njegovih radova, datirano u vrijeme oko 1455 . godine ${ }^{51}$ (slika 5). Upravo takva

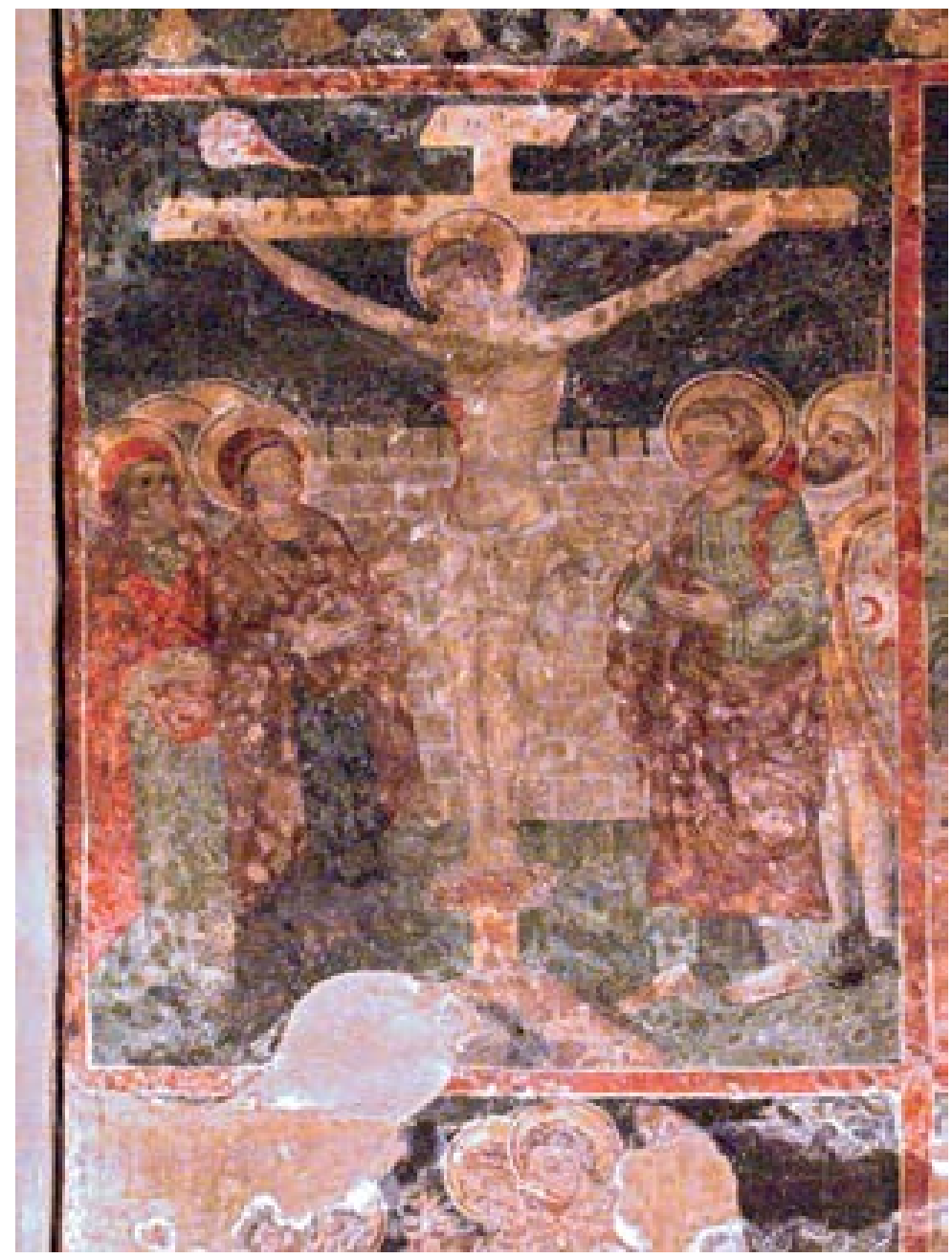

S1. 5. Raspeće, Bogorodičina crkva manastira Savina, pripisano Lovri Dobričeviću (foto: Zoran Đurić)

omogućen ulaz u oltarski prostor u kojem se te freske nalaze. Iz toga razloga, ocjenu stila u potpunosti preuzimam iz: V. J. Đurić, Savina, str. 9.

51 Isto, str. 9-13. 
spremnost da se angažira slikar formiran na tradiciji zapadne umjetnosti, kao što je bio Lovro Dobričević, ${ }^{52}$ svjedoči veliku otvorenost i visoki stupanj tolerancije naručitelja, a ta bi se osobina svakako, prema svemu poznatome iz povijesnih izvora, zasigurno mogla pripisati hercegu Stjepanu. To je još jedan od važnih elemenata koji govore u prilog pretpostavci o tome da je upravo on bio utemeljitelj Bogorodičine crkve u Savini.

Moguće je i da je crkva posvećena sv. Savi u Savini, također, ostavština hercega Stjepana Vukčića Kosače. Najviše u prilog tome govori datacija te malene crkvice koja je podudarna s vremenom kada Stjepan Vukčić sebi dodjeljuje titulu "hercega od sv. Save" i posveta crkve tome svecu. ${ }^{53}$

Posljednja poznata nam ostavština hercega Stjepana je crkva na Zagrađu iznad Šćepan Polja, lokalitetu koji pripada Soko gradu (slika 6). Iako ne postoje dokumenti kojima se potvrđuje da je herceg Stjepan podigao tu crkvu, niti natpis na crkvi koji bi to dokazivao, smatramo kako nema dvojbi oko toga. Crkva je podignuta u gradu Sokolu, gradu kojega je razvio njegov neposredni prethodnik, vojvoda Sandalj i koji je bio hercegov "slavni dvor", što se čita iz brojnih dokumenata u kojima je Stjepan Vukčić Kosača određen kao "de Sochol" ili "de "Zokol". ${ }^{54}$ Činjenica da u blizini nije bilo drugih gradova, također pojačava tu pretpostavku, a osobito je u tom smislu važna narodna tradicija koja čuva uspomenu na "hercegovu crkvu" misleći na crkvu u Zagrađu. ${ }^{55}$

Crkva je jedna od najvećih i najreprezentativnijih sakralnih građevina podignutih sredinom 15. stoljeća u srednjovjekovnome Zahu-

52 Dobričević, Lovro Marinov, hrvatski slikar (Kotor, ? - Dubrovnik, 1478.). Školovao se u Veneciji. Djelovao u Kotoru i Dubrovniku, gdje je otvorio veliku radionicu s mnogobrojnim pomoćnicima i; u njoj je izrađivao poliptihe i slike za Dubrovnik i dubrovačku okolicu, ali i za naručitelje iz Bosne. Dobričević je najistaknutiji umjetnik XV. st. u Dubrovniku, a njegova djela pokazuju stilsku evoluciju od ranijih, tvrđih gotičkih oblika prema ranorenesansnom shvaćanju volumena i kompozicije pod utjecajem ranoga slikarstva Antonija Vivarinija. "Lovro Marinov Dobričević", u: Hrvatska likovna enciklopedija, 3, Zagreb, 1964., str. 342.

53 D. Vojvodić, nav. dj., str. 64; Lj. Stojanović, nav. dj., str. 64, br. 663.

54 Minajlo Dinić, Srpske zemlje u srednjem veku, Beograd, 1978., str. 183, 195; Desanka KovačEvić-KoJIĆ, Gradska naselja srednjovjekovne bosanske države, Sarajevo, 1978., str. 104; D. VoJvodić, nav. dj., str. 66.

D. VoJvodić, nav. dj., str. 65-66. 

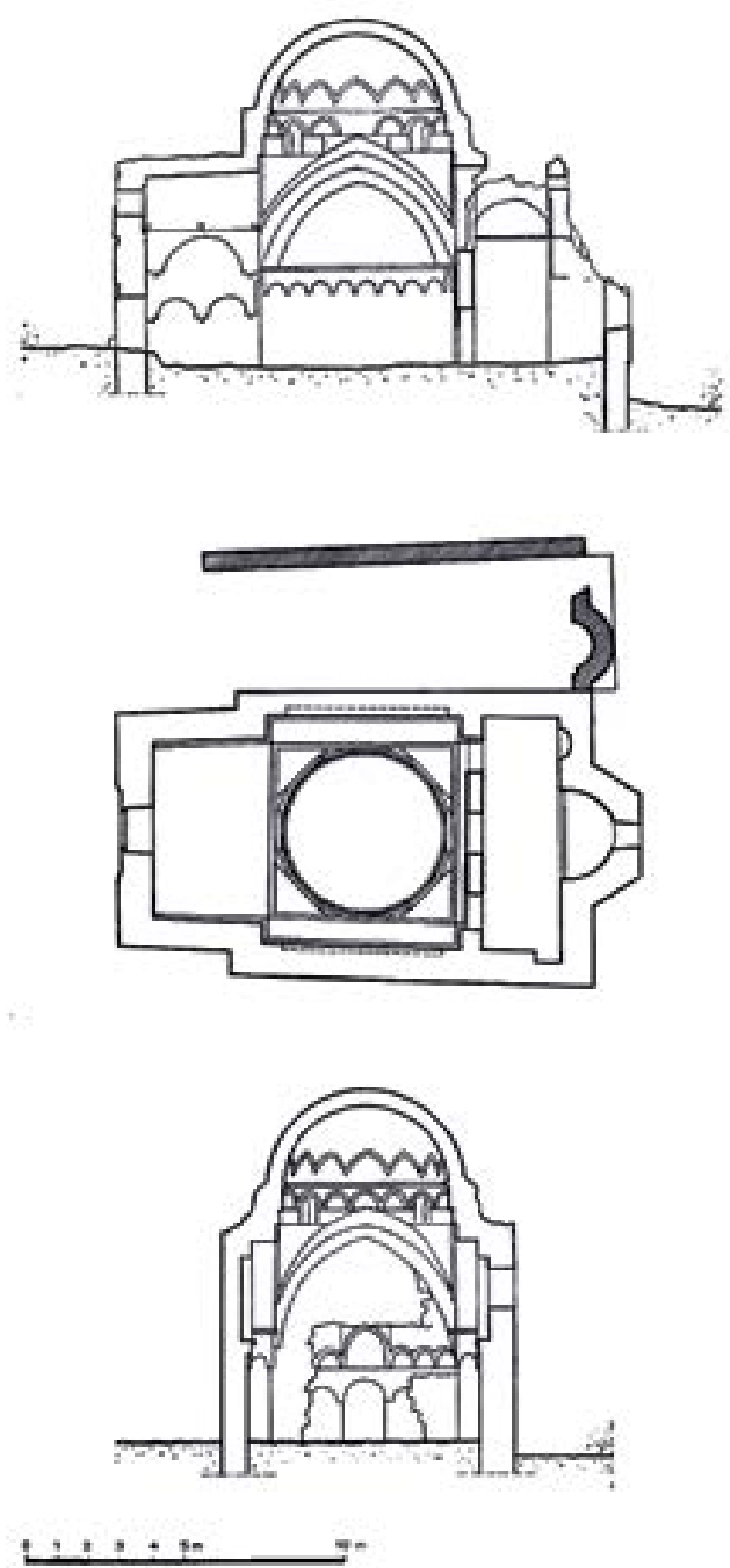

Sl. 6. Crkva u Zagrađu

Preuzeto iz: Dragan VoJvodić, "Ktitorska delatnost Stjepana Vukčića Kosače", u: Šćepan polje i njegove svetinje kroz vjekove - Zbornik radova sa naučnog skupa, Berane, 2010., str. 91. 
mlju. ${ }^{56}$ Tlocrt te crkve je nepravilan pravokutnik, sužen na zapadu, s malim proširenjem srednjega traveja iznad kojeg se dizala kupola. Istočni travej, najkraći, $s$ jednom iznutra polukružnom, a izvana trokutastom apsidom i malom nišom u sjevernom dijelu istočnoga zida, odvojen je od naosa zidanom pregradom ikonostasa. Prezbiterij i zapadni travej pokriveni su gotičkim prelomljenim svodovima, a iznad središnjega dijela crkve podignuta je kupola neobičnoga oblika i konstrukcije. Uska proširenja perimetralnih zidova u prostoru naosa, odnosno, prostoru ispod kupole, nadvišena su prelomljenim lukom na koji se oslanja kupola. Prijelaz iz četvrtaste osnove u kružnu osnovu tambura izveden je preko jednoga niza trompi i jednoga niza pandantiva. Uz to je unutar kupole dodan čitav niz slijepih lukova. Takva složenost konstrukcije kupole i raščlanjenost elemenata konstruktivne, ali i dekorativne naravi, popraćena je sličnom artikulacijom unutarnjih zidova crkve koji su po svim površinama raščlanjeni plitkim prislonjenim arkadama, lukovima i lezenama. Najinteresantniji je način na koji je slijepim lukovima artikulirana površina zidanoga ikonostasa, gdje se uz tri propisana lučno oblikovana prolaza, nalaze drugi slijepi lukovi - dva velika između prolaza, jedan veliki u gornjoj zoni ikonostasa iznad centralnoga prolaza i jedna slijepa arkada sastavljena od manjih lukova. Izgleda kako crkva nije bila oslikana freskama, ${ }^{57}$ pa ni ikonostas, ali nam ta lučna polja sugeriraju mogućnost da je bilo planirano njihovo oslikavanje, odnosno, izrada fresaka koje su trebale imati funkciju ikona ikonostasa.

Smještaj crkve ispod stolnog hercegova grada, monumentalnost građevine, izraziti trud pokazan u oblikovanju unutrašnjosti crkve, a osobito monumentalni stećak ukazuju na veliku vjerojatnost za pretpostavku o namjeri hercega Stjepana da izgradi svoj mauzolej na tome mjestu. ${ }^{58}$

56 Dužina vanjskog zida iznosi oko $16 \mathrm{~m}$, širina zapadnoga $7 \mathrm{~m}$, istočnoga $9 \mathrm{~m}$, a visina je dosezala do $11 \mathrm{~m}$. Vidi: M. Popović, nav. dj., str. 29.

57 Različita su mišljenja o tome je li crkva u Zagrađu bila završena i posvećena prije 1465. godine, godine kada su Turci osvojili Šćepan Polje. V. J. Đurić je iznio takvu tvrdnju, a nju je prihvatio i M. Popović. Međutim, D. Vojvodić zagovara suprotnu teoriju koju temelji na podatku da je crkva bila ožbukana, ne i oslikana te da je naknadno bila dograđena kapela sa sjeverne strane. Vidi: VoJISLAV J. ĐuRIĆ, Istorija srpskog naroda, knj. II., Beograd, 1982., str. 348; M. Popović, nav. dj., str. 33; D. VoJvodić, nav. dj., str. 67.

M. Popović, nav. dj., str. 33; D. Vojvodić, nav. dj., str. 67. 
Osim navedene tri crkve za koje se smatra da jesu ostavštine hercega Stjepana, za još neke crkve, već spomenutu crkvu sv. Save u manastiru Savina ili crkvu sv. Srđa i Bakha na Podima kod Herceg Novoga, opravdano se pretpostavlja da su izgrađene po njegovoj želji. ${ }^{59}$

Također, džamije u Ključu kod Gacka ili u Samoboru na Drini nedaleko od Goražda, prema narodnoj tradiciji, izgrađene su na mjestu hercegovih crkava. ${ }^{60}$ Napokon, turski izvori krajem 15. stoljeća navode crkvu u Kuknju, ljetnoj rezidenciji Kosača. ${ }^{61}$ Također, hercegov sin Vlatko je sa svojim rođakom vojvodom Ivanom Crnojevićem između 1473. i 1475. gradio crkvu u Novom, vjerojatno posvećenu sv. Stjepanu. ${ }^{62}$

Sve to jasno ukazuje na dosada neutvrđenu činjenicu kako su herceg Stjepan, ali i Kosače prije, pa čak i poslije njega, bili aktivni u podizanju crkava. Ne ulazeći ovdje u pitanja vjerske pripadnosti, koja se neizbježno nameću zbog poznate, ali nejasne i do kraja neobjašnjene, složene vjerske situacije u srednjovjekovnome Zahumlju i Bosni, potrebno je utvrditi postoje li neka zajednička obilježja crkava Kosača i ako postoje kazuju li nešto o njihovu vjerskom opredjeljenju, shvaćanjima, običajima...

Navedenih pet, odnosno šest crkava, ako prihvatimo prijedlog da je crkvica sv. Save u Savini Hercegova, daju neke smjernice za daljnja istraživanja. Te se crkve mogu podijeliti u dvije glavne skupine.

U prvu skupinu pripadaju crkva na Brezavici, Bogorodičina crkva u manastiru Savina i, veoma vjerojatno, i crkvica sv. Save u istome manastiru. Drugu skupinu čine Sandaljeva crkva sv. Stjepana u Šćepan Polju, crkva sv. Đorđa u Sopotnici kod Goražda i kao podvarijanta, crkva u Zagrađu.

Crkve iz prve skupine slične su po malim dimenzijama, arhitektonskom tipu longitudinalne jednobrodne građevine s polukružnom apsidom na istočnoj strani i načinu svođenja. U crkvi na Brezavici i Bogorodičinoj crkvi u Savini, ti svodovi poduprti su pojasnicama oslonjenima na plitke lezene prislonjene uza sjeverni i južni zid crkve. U takvoj arhitekturi nije moguće utvrditi neke važnije osobine

59 D. Vojvodić, nav. dj., str. 67 sa starijom literaturom.

60 Isto, str. 65 sa starijom literaturom.

61 Isto.

62 V. J. Đurić, nav. dj., str. 257. 
stila, iako oblik svoda, prozorskih otvora i škrte klesane dekoracije u Brezavici, ukazuju na povezanost s gotičkim graditeljstvom.

Iako na crkvama u Savini nema elemenata klesane dekoracije u kojoj bi se očitovala povezanost $s$ gotičkom umjetnosti, u Bogorodičinoj crkvi toga manastira sačuvan je izraziti primjer gotičke umjetnosti u prvome sloju fresaka kojima je ukrašen prostor prezbiterija. To, kao i oblik luka i svoda, jednako kao i pojave gotičke dekoracije u klesanoj ornamentici u Brezavici, daje nam razloga zaključiti kako su naručitelji tih crkava bili tolerantni prema unošenju novih i drugačijih umjetničkih tradicija, odnosno, da su bili naviknuti na stalnu izmjenu ili stalno istodobno prisustvo umjetničkih ostvarenja vezanih za oba umjetnička, kulturna i vjerska prostora kojima se nalazio na razmeđu, što predstavlja najvažniju osobinu prostora kojima su vladali Kosače. Položaj između istoka i zapada, istoka koji je bio na umoru, iscrpljen sve žešćim sukobima s rastućom osmanlijskom opasnosti i zapada kojega je zbog snažnoga i brzoga razvoja bilo sve teže pratiti, rezultirao je sporadičnim prihvaćanjem pojedinih elemenata iz oba ta kulturna kruga, bez nastojanja na ostvarivanju čistoće izričaja. To se još jasnije može prepoznati u crkvama druge grupe, većim i složenijim sakralnim građevinama, kojima glavne sličnosti predstavljaju veće dimenzije, složeniji tlocrti i gornje konstrukcije te zidani ikonostasi... Kod oblikovanja tih crkava možemo primijetiti i nastojanje da se na svojevrstan način iskaže i posebnost vezana za teritorij na kojemu se one grade i vlastelu koja ih naručuje za svoje posljednje počivalište, odnosno, izvjesne osobine koje bi se mogle povezati s prostorom Zahumlja.

Crkva sv. Stjepana i crkva sv. Đorđa u svojim prvotnim oblicima imaju gotovo jednak tlocrt. Taj tlocrt se u literaturi naziva "drinskim tipom" kojim se iskazuje takozvana "raška renesansa", zapravo, vraćanje ili pozivanje na oblike raške arhitekture iz vremena srpske srednjovjekovne države, prije svega na crkvu manastira Mileševa koji se cijelo vrijeme vladavina Kosača nalazio na njihovu teritoriju. ${ }^{63}$ Jedno od glavnih obilježja raške arhitekture jesu pijevnice, bočni prostori prislonjeni uz naos sa sjeverne i južne strane, koje nastaju zbog potreba liturgije, a $\mathrm{u}$ formalnom smislu pretvaraju se $\mathrm{u}$ stilsko obilježje. Pijevnice, odnosno, takvi bočni prostori, jasno se uočavaju u tim dvjema crkvama, dok se u crkvi u Zagrađu oni javljaju, ali u nešto reduciranom obliku, gubeći funkciju, a zadržavajući

63 V. J. ĐuRIĆ, Mileševa i drinski tip..., str. 17-32. 
stilsko značenje. Zajedničko obilježje tim crkvama predstavlja i postavljanje zasebnih svodova različitih visina i oblika iznad pojedinih prostornih jedinica crkve, što se, također, može povezati s načinom presvođavanja crkava u raškoj arhitekturi. Međutim, oblik svodova, a osobito, nepostojanje kupole iznad središnjega prostora znatno ih razlikuje od raške arhitekture u kojoj je kupola predstavljala glavni akcent čitavoga prostora crkve. Ni crkva sv. Stjepana, ni crkva sv. Đorđa nisu imale kupolu, kako nam govore arheološki nalazi. ${ }^{64}$ Obje crkve su bile pokrivene svodovima čiji je presjek bio prelomljeni luk, čija visina i šiljati oblik, osobito svoda u Sopotnici, ukazuju na izvorište u gotičkoj umjetnosti koja je u to vrijeme cvjetala u jadranskome prostoru. Jedino su prostori pijevnica u obje crkve bili pokriveni polukružnim svodovima koji su se nalazili i na manjoj visini. ${ }^{65}$ Zanimljiv je primjer s dograđenim narteksom u Sopotnici, gdje, prema Đ. Mazaliću: "Ne mogući se pomiriti sa onim gotskim svodom i lukovima, naši monasi nadozidaše svoj dio po starom načinu, uobičajenom od starina za male crkve. I ako je bilo malo poteško, ipak nekako sastaviše najprije onaj prvi gotski, poprečni pojas, prepravljajući ga dozidivanjem u polukružni, sa poluobličastim svodom. I danas je taj pojas s jedne strane, sa zapadne, polukružan, dok je sa istočne strane u vrhu oštar." ${ }^{16}$ Iz ovoga, kao i na temelju uočenih karakteristika tih svodova i načina njihove konstrukcije, sa sigurnošću se može zaključiti kako su svodne konstrukcije, pa i ravna stropna konstrukcija kakva je bila izvedena u nartekstu crkve sv. Stjepana u Šćepan Polju, rezultati izravnoga dodira s gotičkim graditeljstvom koje se razvijalo u susjednim primorskim oblastima. Takav zaključak, uz brojne arhivske dokumente potvrđuju praksu srednjovjekovnih vladara iz Bosne i Zahumlja da pozivaju graditelje, ali i ostale majstore, iz gradova na obali radi obavljanja nekih poslova u njihovim gradovima. Gotovo sigurno se može zaključiti kako su primorski graditelji vodili izgradnju obiju crkava na Šćepan Polju. Oblik svoda u narteksu crkve sv. Đorđa, proširenju iz 16. stoljeća, upućuje na rad lokalnih majstora, onih koji su u drugoj polovici 16. stoljeća, u vrijeme snažnog reaktiviranja umjetničke djelatnosti pravoslavnih pod Osmanlijama, zahvaljujući obnovi rada Patrijaršije, svoje stvaranje temeljili na tradiciji srednjovjekovne srpske umjetnosti.

64 M. Popović, nav. dj., str. 22; Đ. Mazalić, nav. dj., str. 30.

65 M. Popović, nav. dj., str. 22; Đ. Mazalić, nav. dj., str. 32.

66 Đ. MAZALIĆ, nav. dj., str. 33. 
Kako vidimo, u vrijeme Sandalja Hranića i Stjepana Vukčića Kosače, utjecaji su bili raznoliki. U prostornoj dispoziciji crkava prepoznaje se povezanost $s$ raškim arhitektonskim oblicima, ali u samome izvođenju jasno se očituju primjese zapadnjačke gotike. Osim u oblicima svodova i lukova, gotika je uočljiva i u elementima klesane arhitektonske dekoracije, na žalost, malobrojnima. Ipak, ono što je pronađeno - ulomci ornamenata karakterističnih za dubrovačku, odnosno, primorsku gotiku - žioka na raboš, dijamantni niz, jajasti štap, tordirano uže - otkrivaju svoje podrijetlo u okrilju zapadnoeuropskih umjetničkih pojava. Na žalost, danas nam nije sačuvan oslik ni u jednoj od tih crkava, ali su sigurni podatci da su crkve sv. Stjepana i sv. Đorđa bile oslikane. Za obje postoji pretpostavka da su ih oslikali dubrovački majstori. ${ }^{67}$ Teško će biti dokazati da je freske u Sandaljevoj crkvi sv. Stjepana doista radio Ivan Ugrinović, ali je činjenica da se godina u kojoj je u dokumentima potvrđen boravak dubrovačkoga slikara kod vojvode Sandalja i pretpostavljeno vrijeme gradnje i dovršetka Sandaljeve grobne crkve podudaraju, što povećava vjerojatnost da je upravo taj majstor oslikao crkvu sv. Stjepana na Šćepan Polju. ${ }^{68}$ Rad Ugrinovićev bi neminovno označio te freske izvjesnim stupnjem gotičkoga izraza, čak i ako su do kraja poštivale tradicionalni ikonografski program istočnokršćanske umjetnosti. ${ }^{69}$

$S$ druge strane, pak, sve tri crkve imaju još jedan zajednički element unutarnje opreme - zidani ikonostas. Ikonostas je jedan od osnovnih elemenata koji karakteriziraju crkve istočnoga obreda, ${ }^{70}$ što govori o

67 V. J. Đurić, nav. dj., str. 243; Z. KAJMAKović, Zidno slikarstvo u BiH, str. 53-58.

68 M. Popović, nav. dj., str. 28.

69 To ne bi bio jedinstveni slučaj. Već smo govorili o freskama u Savini, za koje se pretpostavlja da su ostvarenje Lovre Dobričevića, a i u kasnijim vremenima, pozivani su dubrovački majstori oslikavati crkve u pravoslavnim manastirima, kao što je slučaj Vice Dobričevića, Lovrina sina koji je 1508. godine radio u manastiru Tvrdošu. U svim tim slučajevima od majstora je traženo da rade "more greco", međutim, njihovo osnovno obrazovanje je pretezalo, pa je dolazilo do stvaranja zanimljivih stilskih mješavina.

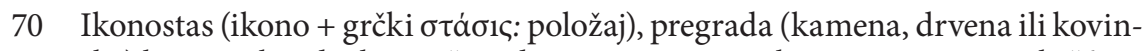
ska) koja u crkvi dijeli svetište od prostora za vjernike. Isprva je u starokršćanskim crkvama pregrada (cancelli, kankeli) bila sastavljena od uzdužnih i poprečnih drvenih ili kamenih greda, potom se preko Bizanta proširila po svim zemljama istočnopravoslavnoga kruga, gdje tijekom vremena polako izrasta $\mathrm{u}$ ikonostas, koji je od 14. st. bio sve bogatije rezbaren i pozlaćivan. U početku je bio nizak, poslije se proteže do stropa i zatvara cijeli oltarski prostor. Ikonostas 
utjecajima koji dolaze iz istočne crkve na oblikovanje crkava u zemlji Kosača. Međutim, ikonostasi čiji se ostatci nalaze u te tri crkve, ${ }^{71} \mathrm{zi}-$ dani, a ne drveni, mogu se smatrati prije dijelom konstrukcije, osloncem gornjih svodnih konstrukcija ili čak i kupole, nego paravanom čija je funkcija nošenje ikona i ostvarivanje simboličkoga značenja. U vrijeme izgradnje tih crkava, kasnom srednjem vijeku upravo se događa promjena oblika ikonostasa koji se od toga vremena, a osobito nakon 16. stoljeća počinje raditi od drveta i prestaju se zidati. ${ }^{72}$ Također, promjena broja vrata, od dvoja u crkvi sv. Stjepana do troja u crkvi na Zagrađu, svjedoči daljnji razvoj oblika ikonostasa, proces u kojem su presudnu ulogu imale Rusija i Sveta Gora i postojanje svijesti o tome i u Zahumlju. ${ }^{73}$

U razmatranju crkava pripisanih Kosačama, onima koje se svrstaju u drugu skupinu, crkva na Zagrađu ponešto odstupa od svega rečenoga. U toj se građevini otkrivaju i neki novi i drugačiji uplivi kakvih nije bilo u nešto ranije podignutim crkvama. $U$ toj crkvi, unatoč činjenici da njezin tlocrt ponavlja slične oblike proizišli iz raške arhitekture, a svodovi prezbiterija i zapadnoga traveja pokazuju isti oblik gotičkoga presjeka kao i u starijima, konstrukcija kupole, ali i opći izgled te crkve sugeriraju izvjesne reflekse osmanlijske arhitekture. Kupola je neobično izvedena. Osnovna silueta građevine i izgled snažne, relativno niske i široke kupole veoma podsjeća na osnovni vanjski oblik osmanlijske džamije. O takvom izvorištu govori i posve neobična kombinacija $\mathrm{i}$ istodobna upotreba trompi i pandantiva pri izgradnji kupole, kao i inventivno korištenje slijepih arkada i lukova koji olakšavaju zidnu masu kalote kupole, a koji se konačno nameću kao izrazito dekorativni element unutar crkve. Takav utjecaj koji potječe iz osmanlijske umjetnosti lako je objasniti vremenom u kojem se crkva gradi, izravnim i čestim kontaktima samoga Hercega

ima troja vrata (srednja, odmah iza oltara, nazivaju se carske dveri). "Ikonostas", u: Hrvatska likovna enciklopedija, 2, Zagreb, 1962., str. 659-662.

71 Tragovi zidanih ikonostasa jasno se vide u crkvama na Šćepan Polju i onoj posvećenoj sv. Stjepanu i onoj u Zagrađu. Međutim, postojanje zidanoga ikonostasa u Sopotnici poznat nam je samo zahvaljujući opisu te crkve u članku (Z)ečevića. Nema razloga sumnjati u istinitost tog opisa, budući da sve ono što je moguće provjeriti, odgovara tome tekstu. Vidi: (Z)EČEvić, nav. dj., str. 244-247.

72 Đ. MAZALIĆ, nav. dj., str. 33.

73 Zoran M. Jovanović, Azbučnik pravoslavne ikonografije i graditeljstva, Beograd, 2005., str. 197. 
s Osmanlijama i neminovnim promjenama do kojih su dovele nove političke prilike i u neposrednoj blizini zemlje Kosača prisutnost Osmanlija i nove vjere i arhitekture koja ju je pratila. Tako se ponovo srećemo s otvorenošću Kosača kao onih koji u svojim crkvama povezuju veoma različite utjecaje koji su posljedice složenih prilika u kojima su živjeli, vladali i nastojali opstati što sigurnije i što duže.

$\mathrm{U}$ svemu tome oni ne zaboravljaju ni na svoje podrijetlo i pripadnost prostoru s kojega potječu. I jedan i drugi vojvoda, dvojica najvažnijih vladara te feudalne obitelji, u svojim ostavštinama koje su trebale biti njihove grobne crkve, određuju mjesto svoga ukopa i označavaju ga monumentalnim stećkom. Upravo se u tom obliku nadgrobnika, obliku tako karakterističnom za srednjovjekovlje Zahumlja i bosanskih prostora, jasno prepoznaje izražavanje svijesti o vlastitom identitetu.

S takvim se pojavama dovršava prikaz osobina sakralne arhitekture nastale pod Kosačama tijekom prve polovice i sredinom 15. stoljeća. To je bila arhitektura koja je odražavala i u kojoj se održavalo sve ono što se događalo u to vrijeme na tom prostoru, tako da zbog složenosti situacije toga doba, ali i kao posljedica stalnog obilježja prostora kojim su Kosače vladale, pozicije na razmeđu religija i kultura, ona govori o ukupnosti graditeljske, umjetničke, ali i vjerske problematike prostora Zahumlja kroz čitav srednji vijek. Prisutnost jakih i čvrsto uobličenih umjetničkih izraza, kao što je bilo raško graditeljstvo, ili gotika na istočnojadranskoj obali, izričaja čvrsto povezanih s vjerskim institucijama koje su se s njima identificirale, uz istodobno periferan položaj u odnosu na važna središta tih umjetničkih pojava, uvjetovali su nastanak zanimljive i složene arhitekture. Svakako je u tome izvjesnu ulogu odigrala i lokalna tradicija, nama još uvijek nedovoljno poznata, kojom se nastojalo ukazati na vlastiti identitet različit od ostalih ili na identitet koji u sebi objedinjuje najbolje od svih susjednih. Takav pristup posjeduje izraziti stupanj otvorenosti i prijemčljivosti za drugo i drugačije, toleranciju i spremnost za prihvaćanje i usvajanje različitih, naizgled nepomirljivih oblika, ali i razvijeni stupanj ukusa i poznavanja umjetničke kvalitete.

\section{Primijenjena umjetnost}

Kosače, kao jedna od najmoćnijih humskih obitelji, morali su posjedovati veći broj umjetnički oblikovanih predmeta. Na žalost, gotovo svi predmeti su danas izgubljeni te nam preostaje osloniti se na opise u izvorima da bismo pobliže odredili stilske karakteristike i funkciju predmeta, odnos obitelji prema djelima likovne umjetnosti te njihovu 
naručiteljsku aktivnost. Unutar studija o naručiteljstvu izdvajaju se dva tipa: naručitelj tj. osoba koja financira izgradnju ili izradu predmeta te svojim odlukama utječe na izgled/oblik predmeta te donator čija je glavna funkcija financijska podrška, ali nema puno utjecaja na sam tijek izgradnje ili izrade predmeta. Proučavanje fenomena naručiteljstva može nam pobliže otkriti kontekst i slojeve kulturalnoga i povijesnoga značenja djela. Također, predmeti namijenjeni privatnoj upotrebi ne podliježu strogim zahtjevima vjerskih potreba i tradicije te održavaju stavove i potrebe osoba za koje su napravljene. Umjetnički oblikovani predmeti/predmeti umjetničkoga obrta bili su i ostali statusni simbol koji govori o ekonomskoj i socijalnoj moći vlasnika, a ukus naručitelja u većoj mjeri može utjecati na oblik, stilske karakteristike te ikonografiju predmeta. Za proučavanje materijalne kulture vezane za obitelj Kosača najznačajniji su izvori koji govore o depozitu obitelji u Dubrovniku, a dragocjeni su i dokumenti koji se odnose na zaloge, poklone, miraze te oporuke članova obitelji. ${ }^{74}$

Opisi predmeta u izvorima su veoma šturi i većinom se odnose na vrstu predmeta i materijal od kojega je predmet izrađen, tako se navodi posuđe, nakit, pojasevi, konjska oprema ali i glazbeni instrumenti. Osim luksuznoga posuđa, Kosače su posjedovale i nekoliko ikona i relikvije; Lilek navodi četiri ikone, jednu malu srebrnu "s' zlamen'jem od' plemeniteh od zamorija", zatim jednu zlatnu ikonicu "s' obrazom' gospogje prečiste" navodeći ukrase poput balasa i bisera, te još dvije male zlatne ikonice. ${ }^{75}$ Opet, teško je govoriti o bilo kakvim stilskim odrednicama, no mogli bismo pretpostaviti da je ikona koju Jelena, udovica Sandaljeva, spominje u svojoj oporuci, uzevši u obzir Jelenino podrijetlo i vjersku pripadnost, imala stilske karakteristike bizantske umjetnosti.

Na osnovi ovako šturih opisa i bez samih predmeta, nemoguće je govoriti o stilskim karakteristikama predmeta u depozitu, no mogu

74 E. Lilek donosi detaljan popis predmeta koji su se nalazili u depozitu, vidi: Emanuel Lilek, "Riznica porodice Hranići (nadimak Kosača)", u: Glasnik zemaljskog muzeja, II., Sarajevo, 1889., str. 1-26; mehanizme i način funkcioniranja dubrovačkog depozita analizira EsAd Kurtović, "Državni deposit (Depozit barunice Anke, Sandalja Hranića i Katarine u Dubrovniku 1406. - 1413. godine)", u: Prilozi, 28, Sarajevo, 1998., str. 57-103; oporuke hercega Stjepana Vukčića Kosače i Jelene, udovice Sandalja Hranića analizira DijANA KORAĆ, "Neki aspekti religioznosti u Kosača", u: Croatica christiana periodica, 72, Zagreb, 2013., 51-72; Dijana Korać, Religioznost humske vlastele u kasnom srednjem vijeku, Crkva na kamenu, Mostar, 2015., str. 159-215. 
se izvući određene pretpostavke o odnosu obitelji prema umjetnički oblikovanim predmetima. Obitelj Kosača je svjesna ekonomske vrijednosti ovih predmeta što je jasno iz njihovih oporuka gdje najvrjednije legate ostavljaju članovima svoje obitelji, no ovi luksuzni predmeti, osim što predstavljaju i ekonomsku sigurnost, govore o želji obitelji da svoju političku/društvenu moć iskaže naručiteljstvom skupocjenih predmeta, ali i angažiranjem stranih majstora, o čemu svjedoči zlatni pojas majstora Vachtera Rambota i "bucat' serpentina" iz oporuke Stjepana Kosače iz 1466. godine. ${ }^{76}$ Bez ugovora o narudžbi pojedinih djela teško je govoriti u kojoj su mjeri pripadnici obitelji Kosača sudjelovali u izradi naručenih predmeta, no možemo predpostaviti da su imali određene zahtjeve pri izradi predmeta poput čaša i hanapa s njihovim grbom/ znamenjem. Sandalj je bio zahtjevan naručitelj rafiniranog ukusa, tako u ugovoru sa zlatarom Živkom Gojakovićem u travnju 1431. godine stoji da, ukoliko se vojvodi ne svidi srebrni vrč koji je naručio, može ga vratiti majstoru. ${ }^{77}$ I članice obitelji Kosača su aktivne naručiteljice. Znamo da je Jelena, udovica Sandaljeva, preko svojega kancelara Doberka Marinovića 1441. godine naručila u Kotoru kod zlatara Andrije Isata srebrne korice za knjige s likom Krista, a Katarina, Sandaljeva supruga, daje izraditi dva relikvijara za crkvu sv. Marije u Zadru. ${ }^{78}$

Kada je riječ o stilu izgubljenih predmeta, u slučaju stranih majstora poput Rambota možemo pretpostaviti jači utjecaj internacionalne gotike, a u talijanizmima koji se često sreću u izvorima, bačin i brokete, na primjer, nalazimo razloge pretpostaviti da su ti predmeti importirani iz Italije, jednako kao i za figuru srebrnoga lava, posebno ako se uzme u obzir da vojvoda Sandalj ulaže novac u Veneciji i tamo posjeduje kuću. ${ }^{79}$

Osim importiranih predmeta, bilo iz Italije ili istočnojadranske obale, jaka je i domaća zlatarska produkcija za koju se može reći

75 E. LILEK, nav. dj., str. 24.

76 E. Lilek, nav. dj., str. 17; C. Fisković, nav. dj., str. 169.

77 C. Fisković, nav. dj., str. 172.

78 Isto, str. 171; EsAD KuRTović, "Doberko Marinić, poslanik bosanskog kralja Stjepana Tomaša", u: MAR Ko KAR Amatić (prir.), Zbornik radova Stoljeća Kraljeve Sutjeske, Franjevački samostan Kraljeva Sutjeska - Kulturno-povijesni institut Bosne Srebrene, Kraljeva Sutjeska - Sarajevo, 2010., str. 100-101.

79 Esad Kurtović, Veliki vojvoda bosanski Sandalj Hranić Kosača, Institut za istoriju, Sarajevo, 2009., str. 358. 
na temelju potvrđenih veza sa srednjom i južnom Dalmacijom i Dubrovnikom kao najvažnijim centrom da je bila bliska zapadnome kulturnome krugu. Bosna je u to doba poznata po rudnicima srebra, stoga dubrovački majstori od 13. stoljeća odlaze u Bosnu.

Znamo da na dvoru hercega Stjepana 1454. godine rade Stipan i Radašin Radosalić. Umjetnička produkcija na istočnojadranskoj obali utječe na ukus u zaleđu, a ovaj transfer olakšava čitav niz bosanskih i humskih mladića koji odlaze u Dubrovnik i postaju šegrtima dubrovačkim zlatarima, a dobar dio njih se vraća u domovinu čime jačaju domaću zlatarsku produkciju. ${ }^{80}$ Ipak, u Bosni koja u srednjem vijeku prima umjetničke impulse iz više različitih središta, uz dominaciju zapadnih oblika prepoznajemo i druge, zajedno prerađene u vlastiti stil koji je zasvjedočen u izvorima kao ad modo bosniensis. M. Wenzel određuje taj stil na osnovi analize ukrašenih srebrnih posuda tzv. hanapa, čiji oblik potječe iz francuske srednjovjekovne umjetnosti. Bosanske specifičnosti ogledaju se u tipu dekoracije ruba hanapa te motiva zmajeva i groteski koje povezuju s umjetnošću stećaka. Za hanape M. Wenzel smatra da su ih bosanski velikaši dijelili svojim vazalima, te za hanap iz Muzeja za umjetnost i obrt predlaže vlasnika Ivana Crnojevića, dok su naručitelji vjerojatno Kosače s obzirom da je Ivan oženio hercegovu kćer Maru. ${ }^{81} \mathrm{U}$ izvorima se pridjev bosanski često spominje uz pojaseve, a iz opisa jasno je da su bili bogato ukrašeni metalnim aplikacijama na baršunu, svili i drugim skupocjenim tkaninama, a ukrašavani su i biserima. Često su ostavljani uza zaloge u dalmatinskim gradovima, te su bili statusni simbol; no bez većega korpusa ovih pojaseva, možemo samo nagađati je li riječ o specifičnom bosanskom stilu. ${ }^{82}$

Na temelju literature i objavljenih izvora teško je odrediti ulogu članova obitelji Kosača u naručivanju luksuznih predmeta, knjiga ili ikona. Istraživanja otežavaju i nejasnoće po pitanju njihove religijske

80 C. Fisković, nav. dj., str. 525-526.

81 Upravo na tom hanapu M. Wenzel definira bosanski stil te predlaže bosansku radionicu kao mjesto izradbe, dok kasnije A. Koprčina sugerira moguće veze sa zadarskim radionicama. Vidi: MARian Wenzel, "A Bosnian Kingdom Metalworking Tradition", u: Peristil, 27-28, Zagreb, 1984.-1985., str. 5-41; Arijana Kor PrČIna, "Prilog poznavanju bosanskih hanapa", u: Radovi Instituta za povijest umjetnosti, 35, Zagreb, 2011., str. 55-64.

82 Mladen Ančić, "Pojasevi i druge dragocijenosti u kasnosrednjovjekovnim obiteljskim riznicama", u: Starohrvatska prosvjeta, III/22, Split, 1995., str. 151-160. 
pripadnosti. No, jasno je da se oni ugledaju na viteške ideale i stil življenja te ovakve obrasce ponašanja prenose u područja kojima vladaju. Stoga zaključujemo s pretpostavkom, smatramo potpuno opravdanom, kako su Kosače bili aktivni naručitelji, bilo u arhitekturi, bilo u ostalim granama umjetnosti, i da se pri naručivanju pokazuje njihov ukus i stavovi.

Svrha ovoga rada bila je, pregledom literature i dostupnih dokumenata, ukazati na fenomen naručiteljstva kod obitelji Kosača te pokušati utvrditi u kojoj mjeri volja naručitelja utječe na finalan umjetnički produkt, bilo da je riječ o arhitekturi ili pak predmetima primijenjenih umjetnosti. Članovi obitelji se mogu povezati s pet sakralnih građevina kojima je zajednička karakteristika da se na njima ogledaju različiti umjetnički utjecaji, od gotičkih utjecaja svojstvenih gradovima na istočnoj obali Jadrana (šiljati svodovi, dekoracija arhitektonske plastike, ostaci fresko oslika), utjecaja raške škole (pijevnice kao karakterističan prostorni element), bizantskih (zidani ikonostasi, ikonografija) te refleksa osmanlijske umjetnosti (kupola crkve u Zagrađu). Kada je riječ o primijenjenim umjetnostima, dominantni su zapadnjački utjecaji, a Dubrovnik je, kao mjesto kontakta bosanske vlastele i zapadnoga kulturnog kruga, trajno izvorište umjetničkih utjecaja i razmjena, iako postoji i mogućnost preradbe različitih utjecaja u autohtoni "bosanski stil", no zbog malog broja sačuvanih umjetničkih predmeta, ovaj stil ostaje nepotvrđen. Kosače su vladale prostorom koji je kontaktno mjesto različitih kulturnih krugova i umjetničkih impulsa, a umjetnička djela nastala pod njihovim patronatstvom odražavaju tu otvorenost prema različitim utjecajima. 


\section{Fine Arts and the Kosaca Family}

\section{Summary}

The paper presents an attempt to reconstruct the lost heritage. We will analyze the relation of the family members of Kosaca to painting. Art-designed objects have been the symbols of power and prestige throughout history, and it is quite certain that the Kosacas also possessed a large number of artworks. Regrettably, as judged by the sources, from the rich treasures of Kosaca there has not been preserved anything to the point that we can safely recognize as the artistic legacy of this great feudal family.

However, there are relatively many references to the members of the Kosaca family in the documents from the Dubrovnik archives, which include artistic items such as icons of the Herzog Stjepan, icons of Jelena, wife of Sandal Hranic and icons of Queen Katarina, jewelry, clothes, and expensive pottery. The Kosacas were also mentioned as architects. There is evidence that Herzog Stjepan raised churches in Stipan field and in Sopotnica near Gorazde. It is well known that Sandalj Hranic owned a palace in $\mathrm{Du}$ brovnik and was fascinated by the work of Ivan Ugrinovic, whom he invited to decorate his residence.

This paper will try to illuminate the Kosaca family relationship with art, their phenomenon of collecting, as well as to point to the strength and importance of the connections between Zahumlje and Dubrovnik and to analyze the modes of artistic influences and tastes between Dubrovnik and the Zahumlje hinterland.

Keywords: the Kosacas; art; architecture; goldsmithing. 